$5 \quad{ }^{1}$ Corresponding Author, Associate Professor (BEng, MEng, PhD, MIEAust), ARC DECRA

6 Fellow, Centre for Offshore Foundation Systems (COFS), The University of Western

7 Australia, 35 Stirling highway, Crawley, WA 6009, Tel: +61 (0)8 6488 7358, Fax: +61 (0)8

$8 \quad 6488$ 1044, Email: muhammad.hossain@uwa.edu.au

$9{ }^{2}$ Former Research Student, Centre for Offshore Foundation Systems, The University of

10 Western Australia, Email: 20263038@student.uwa.edu.au

11

12

13

14 - Number of Words: 4723 (text only)

15 - Number of Tables: 02

16 - Number of Figures: 12 


\section{Perforation Drilling for Easing Spudcan-Footprint Interaction Issues}

\section{ABSTRACT}

19 The interaction between a spudcan and an existing footprint is a major concern during jack-up 20 rig installation. No guidelines were provided in the recently finalised version of ISO 21 guidelines 19905-1 in regards to mitigating spudcan-footprint interaction issues except some 22 proposed considerations due to scarce of detailed investigation. This paper reports a measure 23 for easing spudcan-footprint interaction issues, with the efficiency of perforation drilling tested through model tests carried out at $1 \mathrm{~g}$. The soil conditions tested simulate soft seabed strength profiles close to the mudline, varying the undrained shear strength. The most critical reinstallation locations of $0.5 \mathrm{D}$ and $1 \mathrm{D}(\mathrm{D}=$ spudcan diameter $)$ and existing footprint depth of $0.33 \mathrm{D}$ were investigated. The removal of soil (through perforation) inside the spudcan perimeter, with an area of $9 \%$ perforated, reduced the induced maximum moment, horizontal force, and horizontal sliding distance by up to $80 \%, 83 \%$, and $76 \%$ respectively.

31 Keywords: Clays; Horizontal load; Moment; Perforation drilling; Sliding; Spudcan-footprint interaction. 


\section{INTRODUCTION}

\section{1 'Mobile' Jack-Up Rig and Spudcan-Footprint Interaction Issues}

In the offshore oil and gas industry, 'mobile' independent-leg jack-up rigs are used widely in performing most offshore drilling in water depths up to around $150 \mathrm{~m}$ (CLAROM 1993; Randolph et al. 2005). The rigs are supported on 10 to 20 -m diameter spudcan foundations. There has been a significant increase in the number of rig moves to the sites of the previously installed rig (or rigs) over the last 20 years. This is due to (a) increasing reliance on jack-up rigs for drilling and work-over activities for unmanned and subsea facilities (e.g. drilling additional wells or servicing existing wells); (b) increased jack-up tender assist operations (e.g. installing structures such as jackets, wind turbines); (c) expanding jack-up operational areas due to increased environmental capabilities; (d) reduced time spent at each location, giving increased opportunities for alternative units to operate over the individual field lives (Killalea 2002; Osborne and Paisley 2002; InSafeJIP 2010).

This has in turn caused one of the major concerns to the jack-up industry - interaction between a spudcan and an existing footprint during rig installation (see Figures 1 and 2), especially where the surface layer consists of clayey material. When a spudcan is located on or nearby an adjacent footprint slope, there is a tendency for the spudcan to slide towards the centre of the footprint, inducing excessive lateral forces and bending moments to the rig. Adverse spudcan displacement could result in an inability to install the jack-up in the required position, leg splay, structural damage to the leg, and at worst, bumping or collapsing into the neighbouring operating platform (ISO 2012).

The frequency of offshore incidents during installation near footprints has increased by a factor of four between the period 1979 1988 and 1996 2006 (Osborne 2005) and at an even higher rate over 2005 2012 (Jack et al. 2013). Examples of incidents include (a) leg damage 
to the Mod V class Monitor and 101 jack-up platforms in the Central North Sea (Hunt and Marsh 2004); (b) an exceptionally high RPD reading in the Starboard leg of a jack-up rig due to sliding towards the footprint (Handidjaja et al. 2009); (c) some sliding was experienced by a rig installation as the legs were installed owing to the significantly different leg spacing from the previously installed L780-C Mod II unit (Brennan et al. 2006).

\subsection{Spudcan Footprint Geometry}

On removal of the jack-up unit, the legs are retracted from the seabed, leaving depressions (referred to as a crater or 'footprint') at the site. The depth and configuration of a footprint are a function of several factors. These include (a) the soil type, strength and stratification; (b) the spudcan final penetration depth before extraction; (c) the degree of soil backfill into the cavity above the spudcan during installation, as well as soil infill into the crater beneath the spudcan during and after removal of the spudcan; and (d) the spudcan shape. Over time, the geometry of the footprint may also be affected by the local sedimentary regime. Erbrich (2005), Brennan et al. (2006), Handidjaja et al. (2009) and Teh et al. (2010) reported four case histories, in offshore Australia and Southeast Asia, illustrating the footprints left by the extraction of spudcans. For instance, from bathymetry survey, Handidjaja et al. (2009) illustrated footprints of width $\kappa=\mathrm{x}_{\mathrm{F}} / \mathrm{D}=1.3$ (where $\mathrm{D}=$ spudcan diameter; see Figure 1 for definitions) and depth $\eta=\mathrm{zF} / \mathrm{D}=0.19$ in a layered soil with an undrained shear strength of $\mathrm{su}$ $=20 \mathrm{kPa}$ at the mudline (see Figure $2 \mathrm{a}$ ). The footprint craters consisted of a concave surface with a seabed gradient of about 1:3.5 along the slope. The spudcan foundations were $11.8 \mathrm{~m}$ in diameter and the penetration depths during preloading were 4.3 5.3 m. In a complex layered deposit, Teh et al. (2010) reported footprints of $\kappa=1.03$ and $\eta=0.24$ upon removal of the spudcans of $\mathrm{D}=14.6 \mathrm{~m}$ (see Figure $2 \mathrm{~b}$ ). 
The effect of initial soil strength on the configuration of footprint can be found from the results of half-spudcan tests carried out on clay deposits with various strength profiles (Hossain and Dong 2014). Figure 2c displays the images on soft, lightly over-consolidated clay $\left(\mathrm{s}_{\mathrm{u}}=2.5+3.3 \mathrm{z} \mathrm{kPa}\right)$. It was identified that the crater was mainly influenced by the depth of releasing suction, i.e. detaching the spudcan base from the underlying soil, during extraction. It is somewhat conical in soft clay, with relatively greater depth of sustained suction. During initial penetration of the spudcan, the soil flows towards the surface, which led to surface heave over a wider area around the periphery. This was coupled with the reverse backflow during extraction and dropping of backfilled soil around the periphery (and inside the crater), resulting in a soil hump around the periphery. The total width was 1.92 1.96D. These findings are consistent with Teh et al. (2010).

Clays soften as they are sheared and remoulded by a spudcan penetration-extraction sequence. The reduction in su decreases with the increase in radial distance from the footprint centre and along the depth. A zone of intensely remoulded soil was confined within $0.75 \mathrm{D}$ from the centre. However, the strength regains over the passing of time. After 1.5 years, the soil condition may found to be close to or stiffer than the undisturbed soil (Gan et al. 2012).

\subsection{Previous Work and Existing Measures for Mitigating Spudcan-Footprint}

\section{Interaction Issues}

The influence of spudcan-footprint interaction has been addressed by a number of researchers (e.g. Gaudin et al. 2007; Leung et al. 2007; Cassidy et al. 2009; Gan et al. 2012; Kong et al. 2013). Most of these targeted understanding underlying behaviour. The critical offset ratio $\lambda$ (defined as the ratio of the distance between the footprint centre and spudcan centre, $b$, and the spudcan diameter) was identified as $0.5 \sim 1$ for inducing maximum lateral displacement of 
$104 \sim 0.35 \mathrm{D}$. From case histories, Handidjaja et al. (2009) found that if $\lambda>1.5 \sim 1.7$, the effect of

105 interaction can be neglected, while Teh et al. (2010) reported a minor slip for $\lambda=1$.

106 However, attention to mitigate this issue is sparse. Several measures are suggested or

107 considered for mitigation, including (a) infilling crater (Jardine et al. 2002), (b) capping the

108 infilled crater with gravel loading platforms, (c) stomping (Jardine et al. 2002), (d) successive

109 repositioning until the legs had stabilised in the desired plan position (Brennan et al. 2006), (e)

110 water jetting along with the spudcan preloading (Handidjaja et al. 2009). In relation to case

111 histories in the North Sea, Jardine et al. (2002) and Grammatikopoulou et al. (2007) examined

112 the potential of using the former two. However, the results were mostly unsatisfactory. The

113 pattern of soil movements became markedly asymmetrical (see Figure 3), which led to

114 intolerable forces and moments developing in the jack-up leg before the target preload level

115 was reached. Infilling the crater with different type of soil created additional problems such as

116 punch-through. Gravel loading platform incurred the potential for slope or slope-base failure.

117 In addition, there is no concrete understanding of the mitigation measures and hence no

118 corresponding guidelines in the recently finalised ISO guidelines 19905-1 (ISO 2012). This

119 paper focuses on a mitigation measure of spudcan-footprint interaction issue.

120 An industry practice known as 'perforation drilling' is sometimes used to mitigate punch-

121 through risk in layered clays, extracting soil from the upper strong layer before the jack-up is

122 installed. Operations involve drilling numerous holes from the (yet to be installed) jack-up or

123 a moored coring/drilling vessel (Handidjaja et al. 2004). A straight rotary flush drilling

124 method is used with seawater as a drilling fluid to clean the hole and maintain stability. Two

125 centrifugal pumps provide enough annular velocity to both maintain stability of the large

126 diameter holes ( $\sim 36$ inch) being drilled and circulate clay cuttings out of the hole (Chan et al.

127 2008). The selection of hole size is governed by the available drilling equipment, with holes 
128

129

130

131

132

133

134

135

typically drilled using a 26 36 inch mill tooth tricone bit. Occasionally, a 36 52 inch mill tooth hole opener is used to enlarge the perforations. The perforation drilling technique has been used recently to reinstall jack-ups without incident at several locations in Southeast Asia through layered clays (Maung and Ahmad 2000; Brennan et al. 2006; Kostelnik et al. 2007; Chan et al. 2008). Key normalised parameters from the perforation drilling operations were tabulated by Hossain et al. (2010) as drill diameter to spudcan (D) ratio ddrill/D $=0.047 \sim 0.065$ (or effective hole diameter, $\mathrm{d}_{\text {hole }} / \mathrm{D}=0.059 \sim 0.094$ ) and hole spacing (defined from centre to centre as Shole) to spudcan diameter ratio, Shole/ $\mathrm{D}=0.099 \sim 0.15$. For these ratios the corresponding fraction of soil removed from inside the spudcan perimeter, $\eta_{i}=A_{\text {remi }} / A$ (where $\mathrm{A}_{\text {remi }}$ is the bearing area removed through perforation from inside the spudcan perimeter and $\mathrm{A}$ is the largest plan area of the spudcan), ranged from 13 to $60 \%$.

Hossain et al. $(2010,2011)$ carried out a series model tests at $1 \mathrm{~g}$ and $200 \mathrm{~g}$ and proposed an optimised perforation drilling pattern. As it is impractical to drill a number of holes using a drill bit and drilling fluid on the laboratory floor or in a centrifuge mimicking a typical drilling operation in the field, a single operation drilling tool, referred to as the 'shower head', was developed for carrying out perforation operations effectively within a short period of time. It was showed that the removal of soil inside the spudcan perimeter, with an area of $9 \%$ perforated $\left(\eta_{i}=9 \%\right.$ compared to $13 \sim 60 \%$ in the current practice), eliminated rapid leg run and severe punch-through on the two and four-layer seabed profiles tested. Recently, it has been emphasised repeatedly that perforation drilling may be useful in enabling a jack-up rig to be positioned on a location with existing footprint, mitigating interaction issue (e.g. Maung and Ahmad 2000). These were the motivation of this investigation using the identical drilling pattern. 


\subsection{Objective of Present Study}

153 In an attempt to ease spudcan-footprint interaction issues, this paper reports results from an experimental study investigating the practicability of using perforation drilling. The soil conditions tested simulate soft seabed strength profiles close to the mudline. This was to be consistent with the previous studies exploring the influence of spudcan-footprint interaction (e.g. Gaudin et al. 2007; Leung et al. 2007; Cassidy et al. 2009; Gan et al. 2012; Kong et al. 2013). The footprint dimensions and spudcan reinstallation offset were considered accounting for the critical cases found from previous work and reported field data.

\section{MODEL TESTS}

\subsection{Experimental Program}

163 The experimental tests were performed at $1 \mathrm{~g}$ on the laboratory floor. The tests were carried

164 out in soil confined within a rectangular strongbox, which has (internal) plan dimensions of

$165650 \times 390 \mathrm{~mm}$ and was $325 \mathrm{~mm}$ deep. An actuator was mounted on the strongbox allowing

166 installation of the spudcan (and penetrometer) at a pre-determined rate. The experimental

167 arrangement is shown in Figure 4. Three spudcan tests were undertaken on each sample (or 168 box), including (i) spudcan test on level ground (SL); (ii) spudcan test adjacent to a footprint 169 (SF); (iii) spudcan test on perforated site adjacent to a footprint (SFP) (see Table 1). A total of 17015 tests were carried out on five boxes, as described in Table 1.

171 Spudcan-footprint interaction is a near soil surface (or mudline) problem. Under undrained 172 loadings, the responses at shallow penetration depths depend primarily on cohesive soil 173 strength (Martin and Houlsby 2000). This investigation is carried out at $1 \mathrm{~g}$ with the aim of 174 assessing the performance of perforation drilling at mitigating spudcan-footprint interaction 
175 issues comparing relative spudcan responses adjacent to a perforated and un-perforated

176 footprint. This investigation will be extended through centrifuge model tests and numerical

177 analyses in the future.

\subsection{Model Spudcan}

179 Spudcan penetration tests were performed using a spudcan of $60 \mathrm{~mm}$ diameter (see Figure 3).

180 The model was made from duraluminium and included a $13^{\circ}$ shallow conical underside

181 profile (included angle of $154^{\circ}$ ) and a $76^{\circ}$ protruding spigot. The shape was chosen similar to

182 the spudcans of the 'Marathon LeTourneau Design, Class 82-SDC' jack-up rig, as illustrated 183 by Menzies and Roper (2008).

\subsection{Instrumented Shaft and Sliding Device}

185 The spudcan was rigidly connected to a model leg made from duraluminium, $16 \mathrm{~mm}$ in 186 diameter and $235 \mathrm{~mm}$ long. The leg was instrumented by three sets of bending strain gauges

187 and one set of axial strain gauges (see Figure 4) to record the vertical load applied and the 188 bending moment generated during testing. For allowing horizontal movement to the leg, a 189 special device was fabricated. The key feature of the device was the sliding displacement 190 mechanism allowing free lateral displacement of the leg during the reinstallation. It consists 191 of an immovable rectangular brushed aluminium bracket housing two highly polished non-

192 friction aluminium shafts installed parallel to each other (see Figure 4). This configuration

193 was used to ensure the leg connection underwent no rotation during the testing process. The

194 leg itself was attached to an aluminium block into which the parallel shafts were threaded

195 through. This restricted the block so that it would slide freely only on the horizontal plane. A

196 linear displacement transducer (LDT) was connected to the sliding block to record the lateral

197 displacement. The sliding block could also be 'locked' into place by four circular discs 
198

199

positioned on either side, hence preventing any horizontal displacement. More details can be found in Gaudin et al. (2007).

In the field, the condition of a truss-work leg connected to the hull of a three-leg jack-up unit may be between these two - free sliding and rigidly fixed with no sliding. As such the tests on the last two boxes (B4 B5, Table 1) were carried out without using the sliding device.

\subsection{Sample Preparation}

Five series of tests (Box B1 B5, Table 1) were performed on soft specimens of kaolin clay as an abundance of reliable data regarding the geotechnical properties of kaolin clay is readily available (e.g. as given in Table 2). The soil conditions tested simulate soft seabed strength profiles close to the mudline, varying the undrained shear strength. It was found that undrained shear strengths may be no more than 2 to $15 \mathrm{kPa}$ at seabed level and increase with depth at gradients typically in the range 1 to $2 \mathrm{kPa} / \mathrm{m}$ (Menzies and Roper 2008). In this study, soil deposit with a somewhat uniform strength profile was investigated.

A homogeneous slurry was prepared by mixing commercially available kaolin clay powder with water at $120 \%$ water content (twice the liquid limit) and subsequently de-airing it under a vacuum. The slurry was then carefully ladled into a strongbox and consolidated at $1 \mathrm{~g}$ on the laboratory floor. Three different final consolidation pressures $(50,100$ and $150 \mathrm{kPa})$ were used to achieve three different undrained shear strengths (see Table 1).

\subsection{Soil Strength Determination}

Soil characterisation tests were carried out using a T-bar penetrometer of diameter $5 \mathrm{~mm}$ and length $20 \mathrm{~mm}$. On each box, strength assessments were undertaken immediately before starting spudcan penetration test and after completion of all spudcan tests, facilitating estimation of changes in undrained shear strength $\left(\mathrm{su}_{\mathrm{u}}\right)$ profile over the testing time period. 
221 Typical shear strength profiles are plotted in Figure 5, where $\mathrm{z}$ is the penetration depth at the

222 T-bar mid-diameter and D the spudcan diameter. The measured T-bar resistance was

223 interpreted using the analysis method suggested by White et al. (2010). This method accounts

224 for changes in soil buoyancy and the reduced bearing factor mobilised during shallow 225 embedment. First arbitrary values were considered for the depth of attaining a deep localised 226 failure mechanism and corresponding deep bearing factor of $\mathrm{N}_{\mathrm{T} \text {-bar. }}$ Profiles of initial shear 227 strength and other parameters were calculated. Some iteration was then performed to obtain 228 the actual shear strength profile. For the clay samples considered here, shallow embedment 229 effects prevailed to $\mathrm{z}=135 \sim 210 \mathrm{~mm}$ i.e. up to the full penetration depth of $<120 \mathrm{~mm}$ (see 230 also insert of Figure 5). The results show strength profiles with su reduced by about $1 \mathrm{kPa}$ 231 over a period of $\sim 12$ hours. This is because of swelling of the pre-consolidated soil sample 232 and gradual absorption of ambient water. A reduction of strength of pre-consolidated soil 233 samples was also reported by e.g. Hossain and Randolph (2010) and Hossain et al. (2010). At 234 the conclusion of tests on each box, core samples were collected in order to determine the 235 moisture content, giving average effective unit weight of $\gamma^{\prime}=7,7.12$, and $7.25 \mathrm{kN} / \mathrm{m}^{3}$ for the 236 samples pre-consolidated at 50,100 and $150 \mathrm{kPa}$, respectively.

237 For interpretation of precise undrained shear strength profiles, $\mathrm{Su} / \sigma^{\prime}{ }_{\mathrm{v}}$ can be related to 238 modified Cam clay parameters and over-consolidation ratio (OCR) following Roscoe and 239 Burland (1968), Ladd et al. (1977), and Koutsotas and Ladd (1985) as

$240 \quad \frac{\mathrm{s}_{\mathrm{u}}}{\sigma_{\mathrm{v}}^{\prime}}=\mathrm{aOCR}^{\mathrm{b}}$

241 where $\sigma^{\prime}{ }_{\mathrm{v}}\left(=\gamma^{\prime} \mathrm{z}\right)$ is the vertical effective stress and OCR $=[($ pre-consolidation pressure of 50 242 or 100 or $\left.150 \mathrm{kPa})+\sigma^{\prime}{ }_{\mathrm{v}}\right] / \sigma^{\prime}{ }_{\mathrm{v}}$. The best fit of Equation 1 to the shear strength profiles plotted 243 in Figure 5 was found with values for $\mathrm{a}$ and $\mathrm{b}$ of 0.32 and 0.79 , respectively (see dashed lines 
244 in Figure 5), which are consistent with the values $(\mathrm{a}=0.27$ and $\mathrm{b}=0.79)$ can be obtained

245 using the modified Cam clay parameters of the kaolin clay given in Table 2. Within the scope

246 of this paper, the undrained shear strengths are indicative and used only for normalising 247 maximum moment and horizontal force where a single value is required. As such, the strength 248 profiles were idealised as approximately uniform over the full penetration depths, with a

249 minor effect of softening close to the surface. Table 1 presents a summary of the idealised 250 (and somewhat averaged) soil strengths. The sensitivity of the kaolin is $2.5 \sim 3$.

251 The T-bar and spudcan were penetrated at a rate of $1 \mathrm{~mm} / \mathrm{s}$ and $0.19 \mathrm{~mm} / \mathrm{s}$ respectively, 252 chosen to balance rate effects against ensuring undrained behaviour in clay. The normalised 253 velocity index $v D_{e} / c_{v}$ (where $v$ is the penetration velocity, $D_{e}$ the object effective diameter and $254 \mathrm{c}_{\mathrm{v}}$ the consolidation coefficient for kaolin clay) was around 140, as recommended by Chung 255 et al. (2006) and Low et al. (2008).

\section{$256 \quad 2.6 \quad$ Formation of Footprint}

257 Footprints were not created in a manner in which they usually form, i.e. through spudcan 258 penetration followed by extraction, due to two reasons. First, as discussed previously, Gan et al. (2012) found that the remoulded shear strength will increase with the passing of time and it may be equal or even higher than the intact strength. Second, the tests were carried out at $1 \mathrm{~g}$

261 and as such an impractical time frame (1:1) is required to simulate field situation. As such, 262 craters were created manually on the surface of the consolidated samples.

263 A cutting tool comprised of a mounting frame and cutting blades was developed to create a

264 footprint cavity (Figure 4). The frame was first mounted on the strongbox and the cutting 265 blade was then rotated and cut into the soil forming a cavity of ideal conical shape until the 266 desired footprint depth was reached. This eliminated the heterogeneity in undrained shear 267 strength in a footprint created by spudcan penetration. 
Accounting for Kong et al.'s (2010) findings and based on previous discussion on footprint geometry, craters dimensions were selected as $2 \mathrm{D}$ wide and $0.33 \mathrm{D}$ depth for relatively softer clay deposit (see Table 1). This is consistent and represents the upper bound of the profiles ("Footprint Type B", slope angle of $18.5^{\circ}$ ) presented in Figure 6.

\subsection{Performing Perforation Drilling}

On each box, a spudcan test was conducted adjacent to a footprint with the spudcan vicinity being perforated. The 'shower head' apparatus developed by Hossain et al. $(2010,2011)$ was modified for the $60 \mathrm{~mm}$ diameter spudcan used in this study (instead of $\mathrm{D}=40 \mathrm{~mm}$ ), and employed to perform the perforation drilling. The tool is shown in Figure 7. The water was pumped under a back pressure and was finally channelled through 64 brass tubes. These form a pattern of four circles in the narrow band of $0.9 \mathrm{D}$ to $1.2 \mathrm{D}$. The circumferential and lateral spacing were selected to form an equilateral triangular grid with centre to centre spacing, Shole $/ \mathrm{D}=0.1$ and drill size relative to the spudcan diameter of 0.05 . These various ratios fall within the practical range used offshore as discussed previously in Section 1.3. The length of the tubes below the plate was $1 \mathrm{D}\left(\mathrm{h}_{\text {hole }} / \mathrm{D}=1\right)$.

In a test the shower head was attached to the actuator and positioned over the specific location of the specimen. Holes were created by simultaneously penetrating the tubes in the soil, and injecting water through them (somewhat simulating field drilling using fluid and not just coring). Consequently, the size of the holes was greater than that of the tubes. To circumvent excessive deterioration of the sample, the water flow was terminated once the showerhead reached its final penetration depth. A back pressure of $150 \mathrm{kPa}$ along with the penetration rate of the shower head of $3 \mathrm{~mm} / \mathrm{s}$ was used. Trial tests were conducted to optimise this back pressure and penetration rate. Examples of perforated footprints are shown in Figure 7. The diameter of the holes including washout was about $\mathrm{d}_{\text {hole }} / \mathrm{D}=0.062$ (again falls within the 
292 practical range of $\mathrm{d}_{\text {hole }} / \mathrm{D}=0.059 \sim 0.094$ ) and as such the fractional area removed inside the

293 spudcan perimeter can be computed as 9\%. While carrying out trial testing, the efficiency of

294 the perforating holes was assessed through post-perforation bisection of the drilled site. No

295 hole was found to be closed or collapsed, right down to the full penetration depth of the 296 shower head, neither was closure or collapse of perforated holes observed, at least close to the 297 surface, during execution of the spudcan test at the perforated site. No drilled hole collapse 298 was also found to occur in centrifuge model tests (Hossain et al. 2011; who carried out 299 drilling using the identical method and pattern), and in the field (Maung and Ahmad 2000; 300 Brennan et al. 2006; Kostelnik et al. 2007; Chan et al. 2008).

\subsection{Spudcan Penetration Test}

302 On each soil sample (or box), two footprints were formed $\left(\kappa=2, \eta=0.33, \beta=18.5^{\circ}\right)$. To 303 explore the critical cases, based on the previous discussion, two values of $\lambda$ were selected (see 304 Table 1). First spudcan test (SF) was conducted at an offset of $\lambda=0.5 \mathrm{D}$ (i.e. full spudcan on 305 the footprint slope; see Figure 1) or 1D (i.e. the spudcan tip on the crest of the slope, and 306 hence half of the spudcan on the slope and the other half on the adjacent flat ground) from the 307 footprint centre. For the second test (SFP), perforation drilling concentrically with the 308 spudcan and up to $60 \mathrm{~mm}$ (i.e. 1D) was followed by the spudcan penetration test. The final 309 test was carried on a flat ground (SL).

\section{PERFORMANCE OF PERFORATION DRILLING}

\section{$312 \quad 3.1 \quad$ Typical Response}

313 The vertical penetration resistances are presented in terms of vertical load, $\mathrm{V}$, as a function of

314 spudcan tip penetration depth, dtip. The readings from moment gauges were used to calculate 
315 horizontal force, $\mathrm{H}_{0}$, and moment, $\mathrm{M}_{0}$, at the spudcan base level (referred to as load reference

316 point, LRP, - see Figure 1). They are also plotted against dtip. For the tests with free sliding

317 (Box B1 B3), horizontal displacements, h, are plotted instead of $\mathrm{H}_{0}$. As each box consisted of 318 three tests, one on an unperforated footprint, one after perforation, and one on a flat ground, 319 all corresponding response profiles are included in each figure.

320 The results from tests on Box B1 are shown in Figure 8 (free sliding, $\lambda=0.5, \mathrm{su}_{\mathrm{u}}=11 \mathrm{kPa}$;

321 Table 1). A rapid sliding of $\mathrm{h}=24.8 \mathrm{~mm}$ was recorded for the spudcan penetration adjacent to

322 a footprint without perforation (Figure 8c). The corresponding maximum moment at LRP was

$323 \mathrm{M}_{0}=0.5$ N.m (Figure $8 \mathrm{~b}$ ). Perforation drilling reduced h by $76 \%$ and $\mathrm{M}_{0}$ by $48 \%$. This is

324 because the perforated holes around the periphery of the advancing spudcan provided a

325 preferential penetration path, forcing the spudcan to penetrate somewhat vertically. In

326 addition, this allowed the soil to be compressed rather than flowing back to the surface. This

327 prevented the tendency of sliding significantly. Figure 9 illustrates the associated 328 mechanisms. There was a 51\% reduction of vertical load resistance at the footprint toe level 329 (at $\mathrm{d}_{\mathrm{tip}}=20 \mathrm{~mm}$; see Figure 8a). As expected, the moment and sliding responses for the test 330 on a flat ground (SL) were consistently negligible (e.g. see Figure 8) and hence not included 331 in the discussion.

332 Typical results for rigidly fixed with no sliding condition are illustrated in Figure 10 (Box B4, $\lambda=0.5, \mathrm{su}_{\mathrm{u}}=6 \mathrm{kPa}$; Table 1). For the spudcan penetration adjacent to an unperforated

334 footprint, the maximum moment and horizontal force (above the footprint toe level along the 335 penetration depth) were recorded as $0.12 \mathrm{~N} . \mathrm{m}$ and $1.3 \mathrm{~N}$ (Figures $10 \mathrm{~b}$ and c). A somewhat 336 vertical spudcan penetration by means of perforation drilling has allowed for reducing the 337 induced moment by $75 \%$ and horizontal force by $82 \%$. Again the vertical load resistance was reduced by $49 \%$ (at $d_{\text {tip }}=20 \mathrm{~mm}$; see Figure $\left.10 \mathrm{a}\right)$. 
Two points are worth noted. First, for penetration depths $\leq$ the footprint toe level (i.e. dtip $\leq 20$ $\mathrm{mm}$ ), as expected, the vertical load resistance on a flat ground was consistently higher compared to that on a sloped ground (Figures 8a and 10a) due to lower spudcan base-soil contact area (Kong et al. 2015; Zhang et al. 2015). The difference was more obvious for the

343 free sliding penetration (see Figure 8a). Second, a somewhat S-shaped response profiles can

344 be seen in Figures $10 \mathrm{~b}$ and 10c for the spudcan penetration adjacent to an unperforated 345 footprint (Test SF). This was perhaps partly because of the balancing of various mobilised 346 failure mechanisms (as illustrated by Kong et al. 2015 and Zhang et al. 2015) and 347 corresponding leg splay along the penetration depths of this rigidly fixed (allowing no sliding) 348 spudcan, and partly because of the existence of a profound drop in the corresponding 349 undrained shear strength profile around $80 \mathrm{~mm}$ depth (see Figure 5). Perforation drilling 350 ensured a somewhat vertical penetration and hence eliminated the former, leading to 351 negligible $\mathrm{M}_{0}$ and $\mathrm{H}_{0}$ along the penetration depth. The reduction around $\mathrm{d}_{\text {tip }}=80 \mathrm{~mm}$ was due 352 to the latter (i.e. the drop in the shear strength profile). The resultant was the crossed response 353 profiles from Tests SF and SFP (see Figures $10 \mathrm{~b}$ and 10c).

\section{$354 \quad 3.2 \quad$ Performance of Perforation Drilling}

355 For all tests with and without perforation drilling, a comparison in terms of the magnitude of 356 maximum moment, $\mathrm{M}_{0}$, horizontal force, $\mathrm{H}_{0}$, or sliding distance, $\mathrm{h}$, and maximum vertical 357 load, V, are provided in Table 1. These are presented in Figure 11 in non-dimensional forms, $358 \mathrm{M}_{0} / \mathrm{As}_{\mathrm{u}} \mathrm{D}, \mathrm{H}_{0} / \mathrm{Ass}_{\mathrm{u}}$ and $\mathrm{h} / \mathrm{D}$, as a function of $\lambda$ (as the other parameters relevant to footprint 359 were constant as $\kappa=2, \eta=0.33, \beta=18.5^{\circ}$ ). su values given in Table 1 were used for these 360 normalisations. In general, the values decrease with increasing $\lambda$. This trend is consistent with 361 Kong et al. (2013). All the critical parameters reduce significantly as a result of perforation 
362 drilling, showing the potential of using perforation drilling in easing spudcan-footprint 363 interaction issues.

\section{CONCLUDING REMARKS}

366 The severity of spudcan-footprint interaction issues is quantified by the following measures:

367 induced moment and horizontal force at the spudcan base level and/or distance of the leg

368 sliding towards the footprint toe. The experimental results presented in this paper have shown

369 that perforation drilling can be effective at easing of spudcan-footprint interaction issues 370 during jack-up installation adjacent to existing footprints. With test specimens simulating 371 strength profiles of surface layers, footprint geometry and spudcan installation offset, that

372 caused spudcan-footprint interaction issues to occur, perforating these profiles by only $9 \%$ of

373 the total internal spudcan area concentrically with the installing spudcan consistently reduced

374 the maximum moment, horizontal force and sliding distance by $30 \sim 80 \%, 70 \sim 82 \%$, and $37548 \sim 76 \%$ respectively. The penetration resistance was also reduced up to the depth of 376 perforation, which may have insignificant influence in the field where spudcans penetrate 2 3

377 diameters in soft clay deposits.

378 The results are from preliminary investigations carried out at $1 \mathrm{~g}$. These will be fine-tuned 379 through centrifuge model tests, and on stiff clay deposits. Tests will also be conducted to 380 assess the performance of other potential mitigation measures such as stomping and 381 successive repositioning, and the results will be compared with those achieved using 382 perforation drilling. 


\section{ACKNOWLEDGEMENTS}

385 The first author is an ARC Discovery Early Career Researcher Award (DECRA) Fellow and 386 is supported by the ARC Project DE140100903. The work forms part of the activities of the 387 Centre for Offshore Foundation Systems (COFS), currently supported as a node of the 388 Australian Research Council Centre of Excellence for Geotechnical Science and Engineering 389 and as a Centre of Excellence by the Lloyd's Register Foundation. This support is gratefully 390 acknowledged, as is the assistance of the beam centrifuge technician, Mr. Manuel Palacios. 


\section{REFERENCES}

Acosta-Martinez, H.E., and Gourvenec, S.M. 2006. One-dimensional consolidation tests on kaolin clay. Report Research Report GEO: 06385, Centre for Offshore Foundations Systems, School of Civil and Resource Engineering, The University of Western Australia.

Brennan, R., Diana, H., Stonor, R.W.P., Hoyle, M.J.R., Cheng, C.-P., Martin, D., and Roper, R. 2006. Installing jackups in punch-through-sensitive clays. In Proceedings of the Offshore Technology Conference, Houston, OTC 18268.

Cassidy, M.J., Quah, C.K., and Foo, K.S. 2009. Experimental investigation of the reinstallation of spudcan footings close to exiting footprints. Journal of Geotechnical and Geoenvironmental Engineering, ASCE, 135(4): 474-486.

Chan, N.H.C., Paisley, J.M., and Holloway, G.L. 2008. Characterization of soils affected by rig emplacement and Swiss cheese operations - Natuna Sea, Indonesia, a case study. In Proceedings of the 2nd Jack-up Asia Conference and Exhibition, Singapore.

Chung, S.F., Randolph, M.F., and Schneider, J.A. 2006. Effect of penetration rate on penetrometer resistance in clay. Journal of Geotechnical and Geoenvironmental Engineering, ASCE, 132(9): 1188-1196.

CLAROM 1993. Design guides for offshore structures. Club des Actions de Recherche sur les Ouvrages en Mer, Eds: Le Tirant, P. \& Pérol, C., Paris.

Erbrich, C.T. 2005. Australian frontiers - spudcans on the edge. In Proceedings of the 1st Int. Symp. on Frontiers in Offshore Geotechnics, ISFOG, Perth, pp. 49-74.

Gan, C.T. 2009. Centrifuge model study on spudcan-footprint interaction. PhD Thesis, National University of Singapore, Singapore.

Gan, C.T., Leung, C.F., Cassidy, M.J., Gaudin, C., Chow, Y.K. 2012. Effect of time on spudcan-footprint interaction in clay. Géotechnique, 62(5): 401-413.

Gaudin, C., Cassidy, M.J. and Donovan, T. 2007. Spudcan reinstallation near existing footprints. In Proceedings of the 6th International Offshore Site Investigation and Geotechnics Conference, London, 285-292. 
419 Grammatikopoulou, A., Jardine, R.J., Kovacevic, N., Potts, D.M., Hoyle, M.J.R., and

420

421

422

423

424

425

426

427

428

429

430

431

432

433

434

435

436

437

438

439

440

441

442

443

444

445

446

447 Hampson, K.M. 2007. Potential solutions to the problem of the eccentric installation of jack-up structures into old footprint craters. In Proceedings of the 6th International Offshore Site Investigation and Geotechnics Conference: Confronting New Challenges and Sharing Knowledge, London, 293-300.

Handidjaja, P., Gan, C.T., Leung, C.F., and Chow, Y.K. 2009. Jack-up foundation performance over spudcan footprints analysis of a case history. In Proceedings of the 12th International Conference on the Jack-up Platform Design, Construction and Operation, London.

Hossain, M.S., Cassidy, M.J., Daley, D., and Hannan, R. 2010. Experimental investigation of perforation drilling in stiff-over-soft clay. Applied Ocean Research, 32(1), 113-123.

Hossain, M.S., Cassidy, M.J., Baker, R., and Randolph, M.F. 2011. Optimisation of perforation drilling for mitigating punch-through in multi-layered clays. Canadian Geotechnical Journal, 48(11): 1658-1673.

Hossain, M.S., and Dong, X. 2014. Extraction of spudcan foundations in single and multilayer soils. Journal of Geotechnical and Geoenvironmental Engineering, ASCE, 140(1): 170-184.

Hunt, R.J., and Marsh, P.D. 2004. Opportunities to improve the operational and technical management of jack-up deployments. Marine Structures, 17(3-4): 261-273.

InSafeJIP 2010. Improved guidelines for the prediction of geotechnical performance of spudcan foundations during installation and removal of jack-up units. Joint Industry Funded Project.

ISO 2012. Petroleum and natural gas industries - Site specific assessment of mobile offshore units - Part 1: Jack-ups. International Organization for Standardization, ISO 19905-1.

Jack, R.L., Hoyle, M.J.R., Smith, N.P., and Hunt, R.J. 2013. Jack-up accident statistics - A further update. In Proceedings of the 14th International Conference on the Jack-up Platform Design, Construction and Operation, London.

Jardine, R.J., Kovacevic, N., Hoyle, M.J.R., Sidhu, H.K., and Letty, A. 2002. Assessing the effects on jack-up structures of eccentric installation over infilled craters. In 
Proceedings of the International Conference Offshore Site Investigation and Geotechnics - 'Diversity and Sustainability', London, 307-324.

Killalea, M. 2002. Jackup footprint, punch through studies underway. Drilling Contractor, 43.

Kong, V.W., Cassidy, M.J., and Gaudin, C. 2010. Spudcan reinstallation near existing footprints. In Proceedings of the 7th International Conference on Physical Modelling in Geotechnics, Zurich, 2, 1033-1038.

Kong, V.W., Cassidy, M.J., and Gaudin, C. 2013. Experimental study of the effect of geometry on reinstallation of jack-up next to footprint. Canadian Geotechnical Journal, 50(5): 557-573.

Kong, V.W., Cassidy, M.J., and Gaudin, C. 2015. Failure mechanisms of a spudcan penetrating next to an existing footprint. Theoretical and Applied Mechanics Letters, 5(2): 64-68.

Kostelnik, A., Guerra, M., Alford, J., Vazquez, J., and Zhong, J. 2007. Jackup mobilization in hazardous soils. SPE Drilling \& Completion, 22(1): 4-15.

Koutsoftas, D., and Ladd, C. 1985. Design strengths for an offshore clay. J. Geotech. Engrg., 10.1061/(ASCE)0733-9410(1985)111:3(337), 337-355.

Ladd, C.C., Foot, R., Ishihara, K., Poulos, H.G., and Schlosser, F. 1977. Stress deformation and strength characteristics. State-of-the-Art-Paper, In Proceedings of the 9th ICSMFE, 2, pp. 1087-1092.

Leung C.F., Gan C.T., and Chow Y.K. 2007. Shear strength changes within jack-up spudcan footprints. In Proceedings of the 17th International Offshore and Polar Engineering Conference, Lisbon, 2, 1504-1509.

Low, H.E., Randolph, M.F., DeJong, J.T., and Yafrate, N.J. 2008. Variable rate full-flow penetration tests in intact and remoulded soil. In Proceedings of the 3rd International Conference on Geotechnical and Geophysical Site Characterisation, Taipei, pp. 10871092.

Maung, U.M., and Ahmad, C.K.M. 2000. Swiss cheesing to bring in a jack-up rig at Anding location. In Proceedings of the IADC/SPE Asia Pacific Drilling Technology, Kuala Lumpur, IADC/SPE 62755. 
477

478

479

480

481

482

483

484

485

486

487

488

489

490

491

492

493

494

495

496

497

498

499

Menzies, D., and Roper, R. 2008. Comparison of jackup rig spudcan penetration methods in clay. In Proceedings of the 40th Offshore Technology Conference, Houston, OTC 19545.

MSL 2004. Guidelines for jack-up rigs with particular reference to foundation integrity. In MSL Engineering Limited for the Health and Safety Executive, Research Report 289.

Osborne, J.J. 2005. Are we good or are we lucky? OGP/CORE Workshop, Singapore.

Osborne, J.J., and Paisley, J.M. 2002. S E Asia jack-up punch- throughs: the way forward? In In Proceedings of the Offshore Site Investigation and Geotechnics - Diversity and Sustainability, London, pp. 301-306.

Randolph, M.F., Cassidy, M.J., Gourvenec, S., and Erbrich, C.J. 2005. Challenges of offshore geotechnical engineering. State of the Art paper, In Proc. Int. Conf. on Soil Mech. and Found. Eng., Osaka 1, pp. 123-176.

Roscoe, K.H., and Burland, J.B. 1968. On the generalised stress-strain behaviour of 'wet' clay. In Engineering plasticity. Cambridge: Cambridge University Press, 535-609.

Stewart, D.P. 1992. Lateral loading of piled bridge abutments due to embankment construction. PhD Thesis, The University of Western Australia.

Teh, K.L., Handidjaja, P., Leung, C.F., and Chow, Y.K. 2010. Leg penetration analysis of jack-up rig installation over existing footprints. In Proc. $20^{\text {th }}$ Int. Offshore and Polar Engineering Conf., Beijing 2, pp. 427-433.

Zhang, W., Cassidy, M.J., and Tian, Y. 2015. 3D large deformation finite element analyses o jack-up reinstallations near idealised footprints. In Proceedings of the 15th International Conference on the Jack-up Platform Design, Construction and Operation, London. 
500 Nomenclature

501 A spudcan plan area at largest section

502 Aremi bearing area removed through perforation from inside spudcan perimeter

$503 \mathrm{~b} \quad$ offset distance

$504 \quad c_{v} \quad$ coefficient of consolidation

$505 \mathrm{D}$ foundation diameter at largest section

$506 \quad \mathrm{D}_{\mathrm{e}} \quad$ object (area equivalent) diameter

$507 \quad \mathrm{~d}_{\text {tip }} \quad$ penetration depth of spudcan tip

508 ddrill drill bit or tube outer diameter

509 dhole hole diameter

$510 \quad \mathrm{H}_{0} \quad$ horizontal force at spudcan base level

$511 \mathrm{~h} \quad$ horizontal sliding distance

$512 h_{\text {hole }}$ hole depth

$513 \mathrm{M}_{0} \quad$ moment at spudcan base level

514 Shole hole spacing

$515 \mathrm{Su} \quad$ undrained shear strength

$516 \mathrm{~V} \quad$ vertical force

$517 \quad \mathrm{~V} \quad$ object penetration velocity

$518 \quad \mathrm{XF} \quad$ footprint diameter 
$519 \quad \mathrm{z} \quad$ depth below soil surface

$520 \quad$ ZF footprint depth

$521 \quad \beta \quad$ footprint angle

$522 \eta \quad$ ratio between footprint depth and spudcan diameter $=\mathrm{zF}_{\mathrm{F}} / \mathrm{D}$

$523 \eta_{\mathrm{i}} \quad$ fraction of soil removed through perforation from inside the spudcan perimeter

$524 \quad \sigma^{\prime}{ }_{v} \quad$ vertical effective stress

$525 \quad \gamma^{\prime} \quad$ soil effective unit weight

$526 \kappa \quad$ ratio between footprint diameter and spudcan diameter $=\mathrm{xF}_{\mathrm{F}} / \mathrm{D}$

$527 \lambda \quad$ ratio between offset distance and spudcan diameter $=\mathrm{b} / \mathrm{D}$

528 
Table 1. Summary of model tests conducted $(D=60 \mathrm{~mm})$

\begin{tabular}{|c|c|c|c|c|c|c|c|c|c|c|c|c|c|c|c|c|c|c|}
\hline \multirow[t]{3}{*}{ Box } & \multirow{3}{*}{$\begin{array}{c}\text { Pre- } \\
\text { Consolidation } \\
\text { pressure }(\mathrm{kPa})\end{array}$} & \multirow{3}{*}{$\begin{array}{l}\text { Undrained } \\
\text { shear } \\
\text { strength, } \mathrm{s}_{\mathrm{u}} \\
(\mathrm{kPa})\end{array}$} & \multirow{3}{*}{$\begin{array}{l}\text { Spudcan } \\
\text { installation } \\
\text { distance, } \lambda \\
=b / D\end{array}$} & \multirow{3}{*}{$\begin{array}{c}\text { Horizontal } \\
\text { displacement }\end{array}$} & \multicolumn{14}{|c|}{ Spudcan tests } \\
\hline & & & & & \multicolumn{2}{|c|}{$\mathrm{M}_{0}$ (N.m) } & \multicolumn{2}{|c|}{$\mathrm{H}_{0}(\mathrm{~N})$} & \multicolumn{2}{|c|}{$\mathrm{h}(\mathrm{mm})$} & \multicolumn{2}{|c|}{$\begin{array}{c}\mathrm{V}(\mathrm{N}) \\
\text { (at footprint toe) }\end{array}$} & \multicolumn{2}{|c|}{$\mathrm{M}_{0} / \mathrm{As}_{\mathrm{u}} \mathrm{D}$} & \multicolumn{2}{|c|}{$\mathrm{H}_{0} / \mathrm{As}_{\mathrm{u}}$} & \multicolumn{2}{|c|}{$\mathrm{h} / \mathrm{D}$} \\
\hline & & & & & $\mathrm{SF}$ & SFP & $\mathrm{SF}$ & SFP & SF & SFP & $\mathrm{SF}$ & SFP & SF & SFP & SF & SFP & $\mathrm{SF}$ & SFP \\
\hline B1 & 100 & 11 & 0.5 & Free & 0.50 & 0.26 & - & - & 24.80 & 6.00 & 129.8 & 63.10 & 0.27 & 0.14 & - & - & 0.41 & 0.10 \\
\hline B2 & 150 & 16 & 1 & Free & 0.45 & 0.23 & - & - & 16.40 & 8.60 & 92.60 & 54.80 & 0.17 & 0.09 & - & - & 0.27 & 0.14 \\
\hline B3 & 150 & 16 & 0.5 & Free & 0.60 & 0.42 & - & - & 17.30 & 6.70 & 131.60 & 57.70 & 0.22 & 0.16 & - & - & 0.29 & 0.11 \\
\hline B4 & 50 & 6 & 0.5 & Locked & 0.12 & 0.03 & 1.30 & 0.23 & - & - & 115.50 & 59.10 & 0.12 & 0.03 & 0.077 & 0.014 & & \\
\hline B5 & 100 & 11 & 1 & Locked & 0.10 & 0.02 & 0.60 & 0.18 & - & - & 101.10 & 56.30 & 0.05 & 0.01 & 0.019 & 0.006 & & \\
\hline
\end{tabular}

530 SF: spudcan test adjacent to a footprint

531 SFP: spudcan test on perforated site adjacent to a footprint

532 Footprint dimensions: Depth, $\eta=\mathrm{zF}_{\mathrm{F}} / \mathrm{D}=0.33$; Width, $\kappa=\mathrm{x}_{\mathrm{F}} / \mathrm{D}=2$; Slope angle, $\beta=18.5^{\circ}$

\begin{tabular}{|l|l|}
\hline Property & Value \\
\hline Liquid limit, LL: \% & 61 \\
\hline Plastic limit, PL: \% & 27 \\
\hline Plasticity index, $\mathrm{I}_{\mathrm{p}} \%$ & 34 \\
\hline Specific gravity, $\mathrm{G}_{\mathrm{s}}$ & 2.6 \\
\hline Critical state frictional constant, $\mathrm{M}$ & 0.92 \\
\hline Slope of normal consolidation line, $\lambda$ & 0.205 \\
\hline Slope of swelling line, $\kappa$ & 0.044 \\
\hline Parameter $\Lambda=(\lambda-\kappa) / \lambda$ & 0.785 \\
\hline Consolidation coefficient $(\mathrm{mean}), \mathrm{c}_{\mathrm{v}}: \mathrm{m}^{2} / \mathrm{year}$ & $\sim 2.6$ \\
\hline Permeability coefficient $($ at $85 \mathrm{kPa}), \mathrm{k}_{\mathrm{v}}(\mathrm{m} / \mathrm{sec})$ & $1.3 \times 10^{-10} \sim 5.1 \times 10^{-9}$ \\
\hline
\end{tabular}


Fig. 1 Schematic diagram of spudcan-footprint interaction and mitigating perforation drilling

Fig. 2 Geometry of spudcan footprints: (a) Diagram of existing footprints $\left(\eta=\mathrm{zF}_{\mathrm{F}} / \mathrm{D}=0.19, \kappa\right.$

$541=\mathrm{xF} / \mathrm{D}=1.3$ ) and arrangements of a rig emplacement over them (from a case history in offshore Southeast Asia, after Handidjaja et al. 2009); (b) Diagram of existing footprints ( $\eta=$ $543 \mathrm{ZF} / \mathrm{D}=0.24, \kappa=\mathrm{x}_{\mathrm{F}} / \mathrm{D}=1.03$ ) and arrangements of a rig emplacement over them (from a case 544 history in offshore Southeast Asia, after Teh et al. 2010); (c) Footprints from centrifuge tests 545 (after Hossain and Dong 2014)

546 Fig. 3 Measures for mitigating spudcan-footprint interaction (after Grammatikopoulou et al. 547 2007): (a) Vectors of incremental ground displacement - infilled crater; (b) Vectors of 548 incremental ground displacement - infilled crater capped with gravel loading platform

549 Fig. 4 Experimental set-up for a spudcan test on a footprint

550 Fig. 5 Shear strength profiles measured before and after spudcan tests

551 Fig. 6 Comparison of footprint profiles record (after Kong et al. 2010)

552 Fig. 7 Drilling tool shower head and perforated footprints

553 Fig. 8 Results of tests on Box 1: free sliding leg $\left(\lambda=0.5, \kappa=2, \eta=0.33, \beta=18.5^{\circ}\right.$; Table 554 1): (a) Load-penetration response; (b) Moment at spudcan base level; (c) Sliding distance 555 Fig. 9 Effect of perforation spudcan sliding and soil flow mechanisms $(\lambda=1, \kappa=2, \eta=$ $5560.33, \beta=18.5^{\circ}$; Box 2, Table 1): (a) Spudcan penetration adjacent to footprint: sliding with 557 significant soil flow to surface towards footprint toe; (b) Spudcan penetration on perforated 558 site adjacent to footprint: minimal sliding with little soil flow to surface 
559 Fig. 10 Results of tests on Box 4: fixed leg $\left(\lambda=0.5, \kappa=2, \eta=0.33, \beta=18.5^{\circ}\right.$; Table 1): (a)

560 Load-penetration response; (b) Moment at spudcan base level; (c) Horizontal force at spudcan

561 base level

562 Fig. 11 Effect of perforation: free sliding leg $\left(\kappa=2, \eta=0.33, \beta=18.5^{\circ}\right.$; Box 1 3, Table 1):

563 (a) Non-dimensional moment; (b) Normalised sliding

564 Fig. 12 Effect of perforation: fixed leg $\left(\kappa=2, \eta=0.33, \beta=18.5^{\circ}\right.$; Box 4 5, Table 1): (a)

565 Non-dimensional moment; (b) Non-dimensional horizontal force

566 


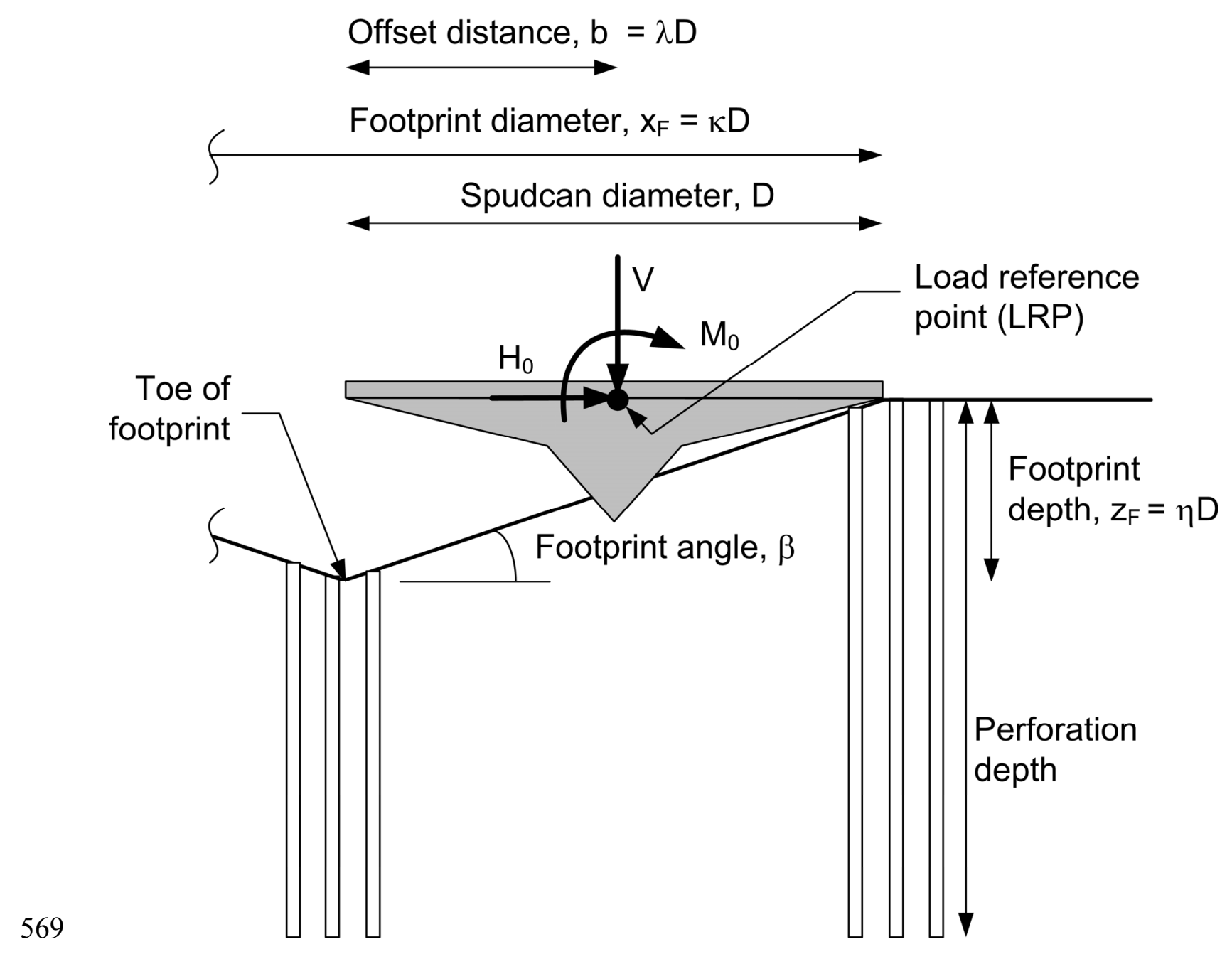



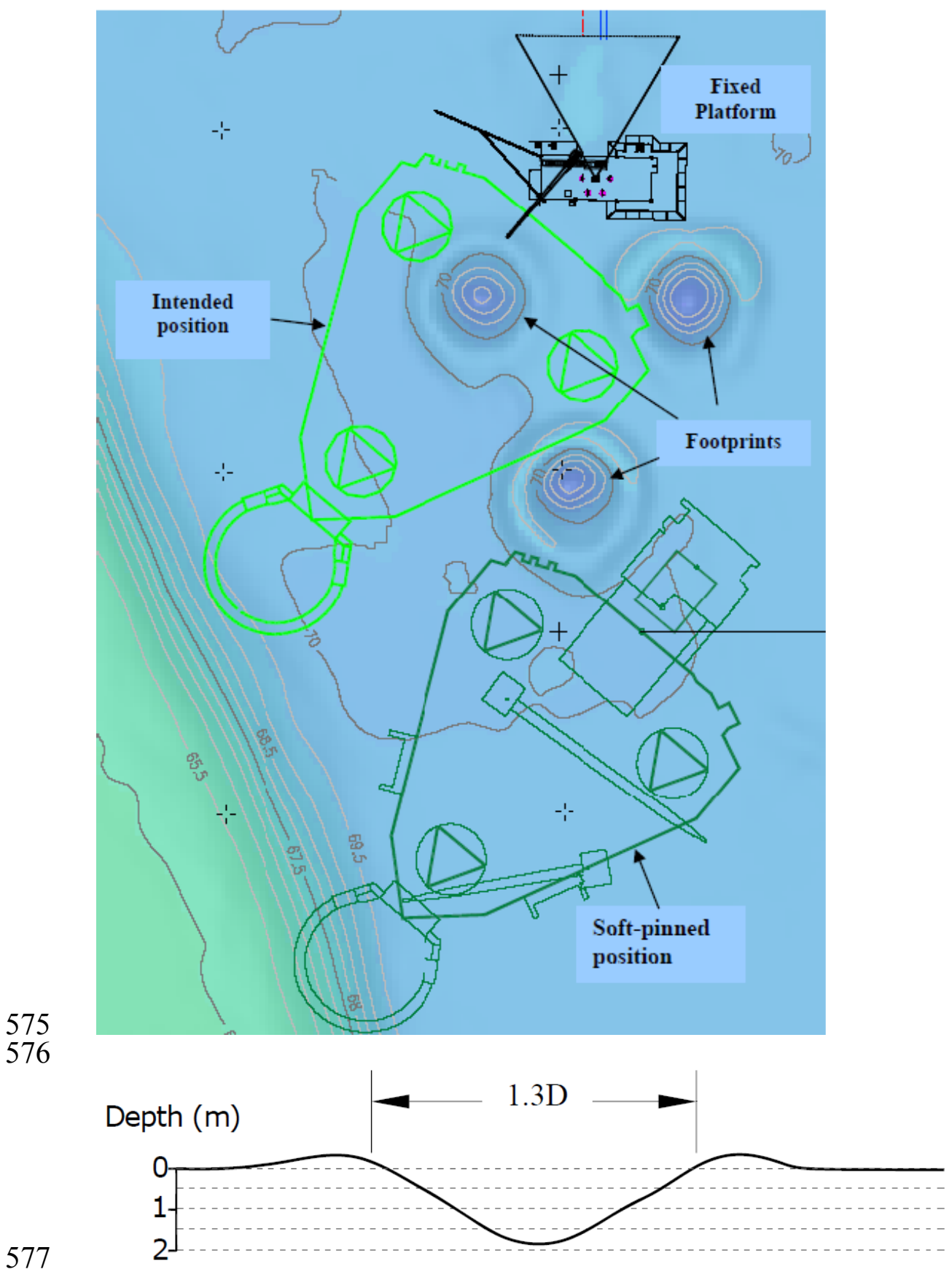

579 2(a) Diagram of existing footprints $\left(\eta=\mathrm{zF}_{\mathrm{F}} / \mathrm{D}=0.19, \kappa=\mathrm{xF}_{\mathrm{F}} / \mathrm{D}=1.3\right)$ and arrangements of a

580 rig emplacement over them (from a case history in offshore Southeast Asia, after Handidjaja et al. 2009) 


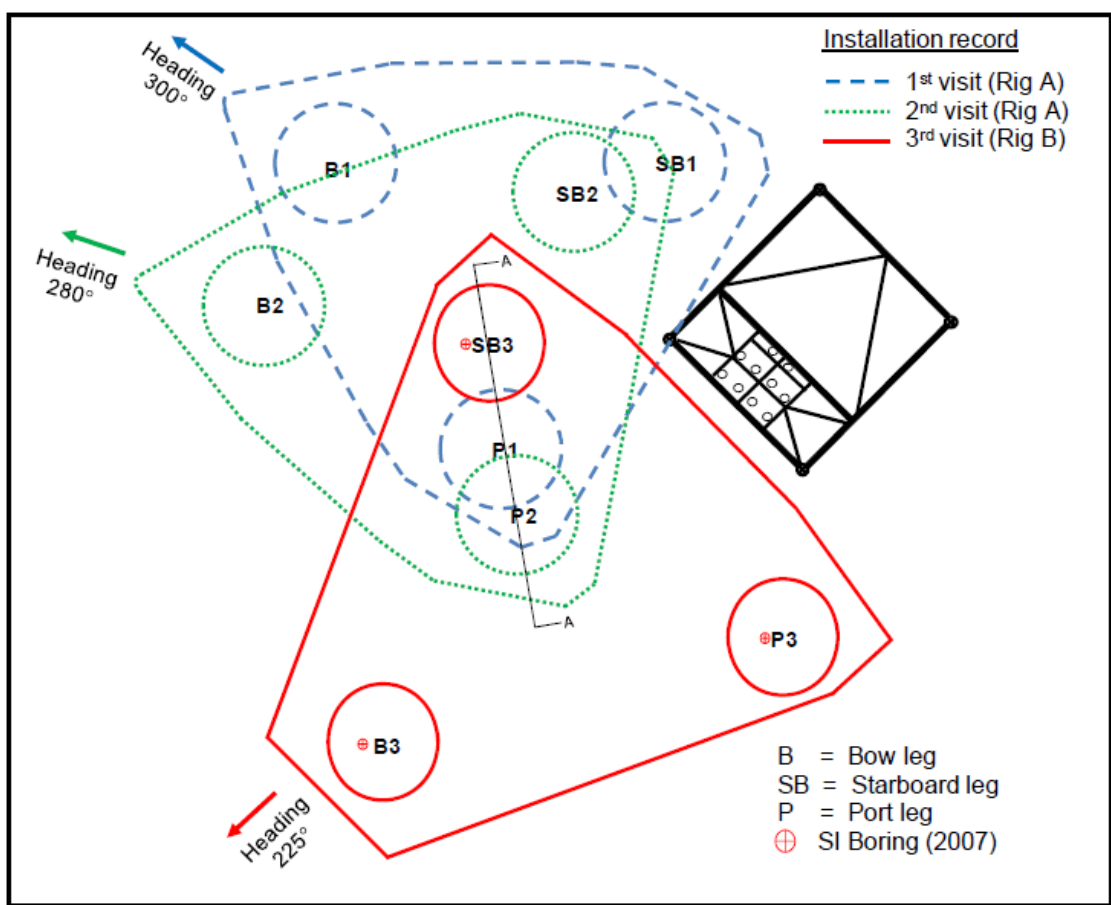

583 2(b) Diagram of existing footprints $\left(\eta=\mathrm{zF}_{\mathrm{F}} / \mathrm{D}=0.24, \kappa=\mathrm{x}_{\mathrm{F}} / \mathrm{D}=1.03\right)$ and arrangements of a

584 rig emplacement over them (from a case history in offshore Southeast Asia, after Teh et al.

585 2010)

586

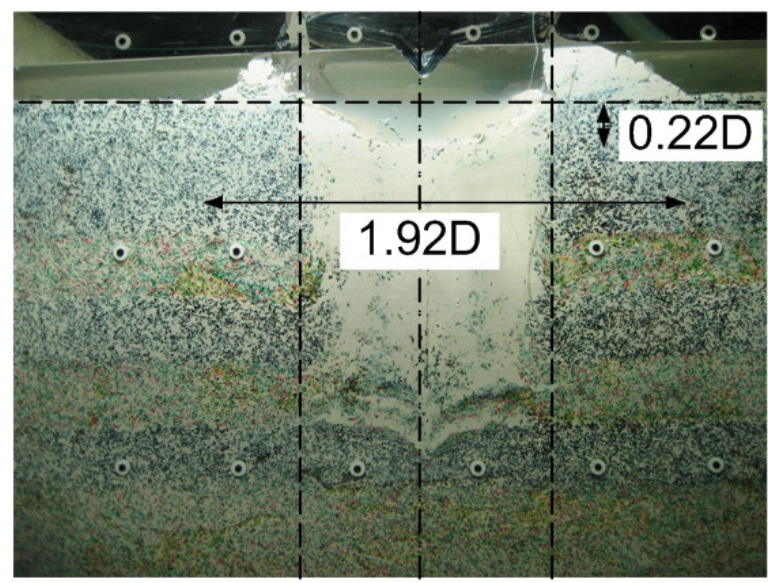

588 2(c) Footprints from centrifuge tests 


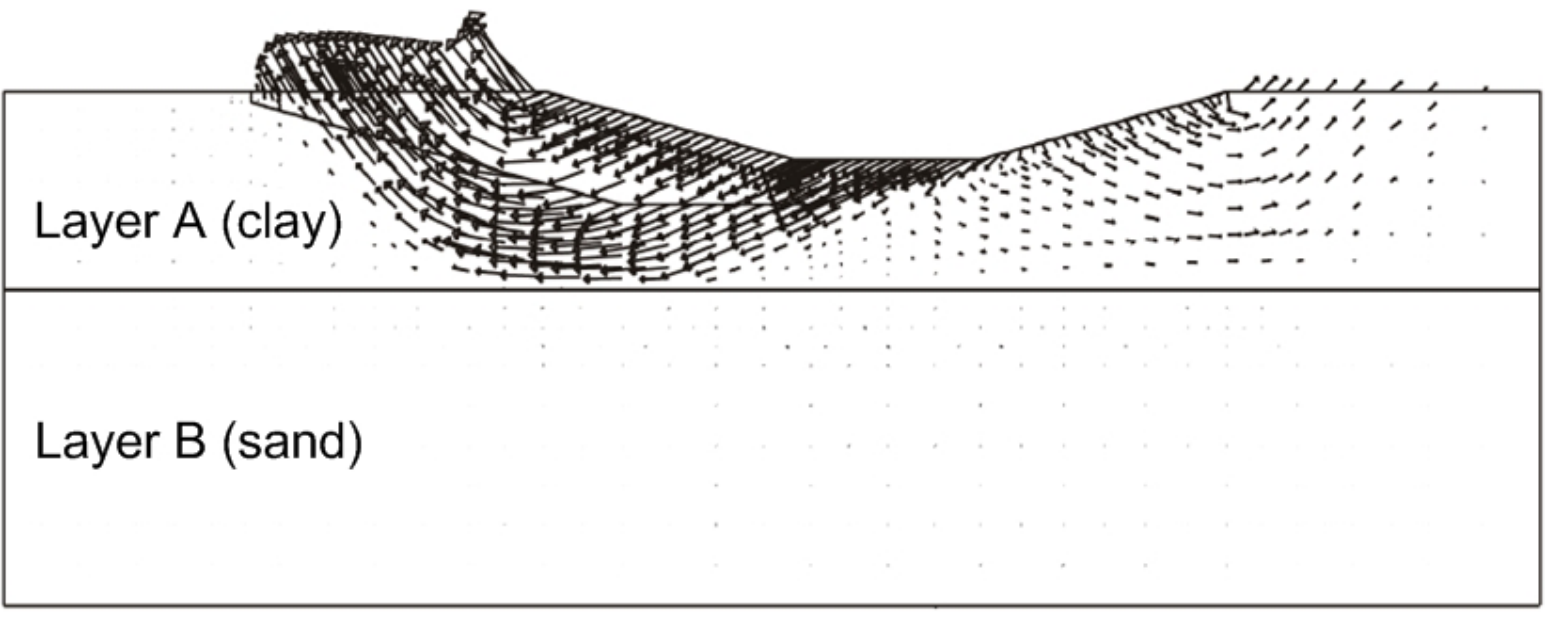

590

591 3(a) Vectors of incremental ground displacement - infilled crater

592

593

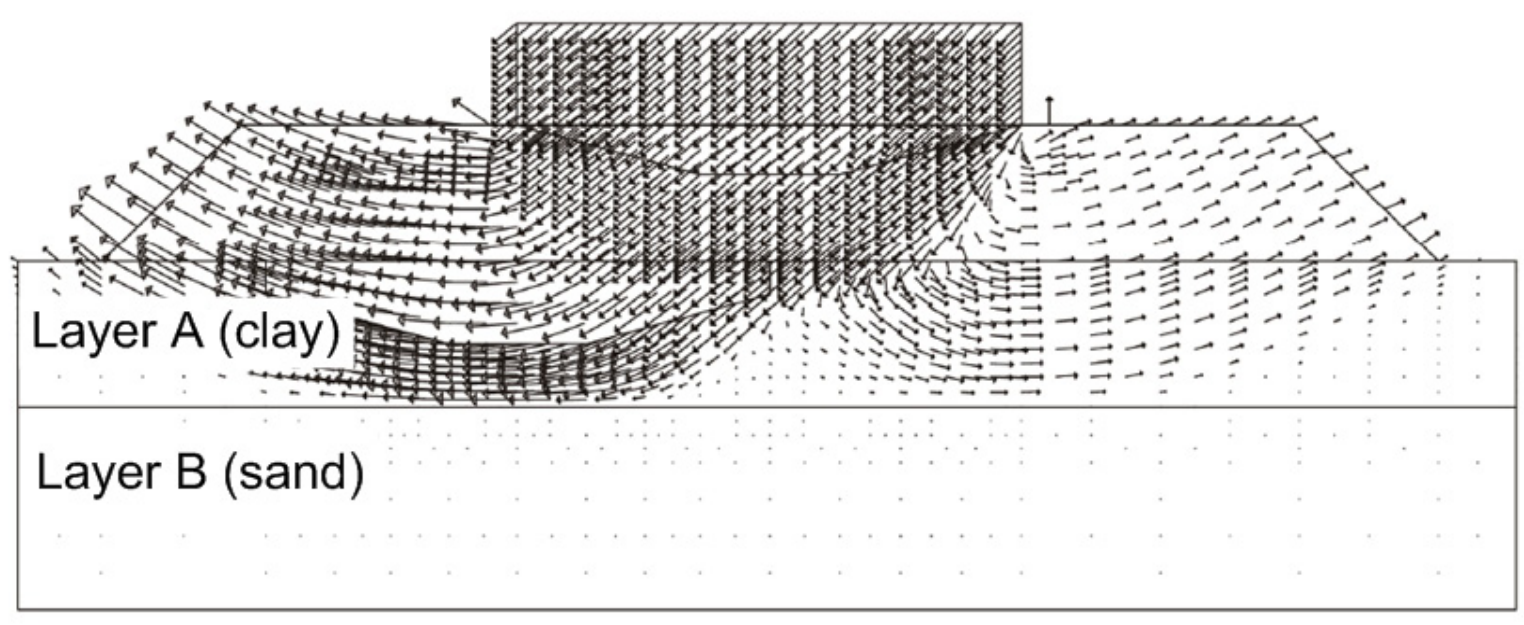

594 3(b) Vectors of incremental ground displacement - infilled crater capped with gravel loading 595 platform 


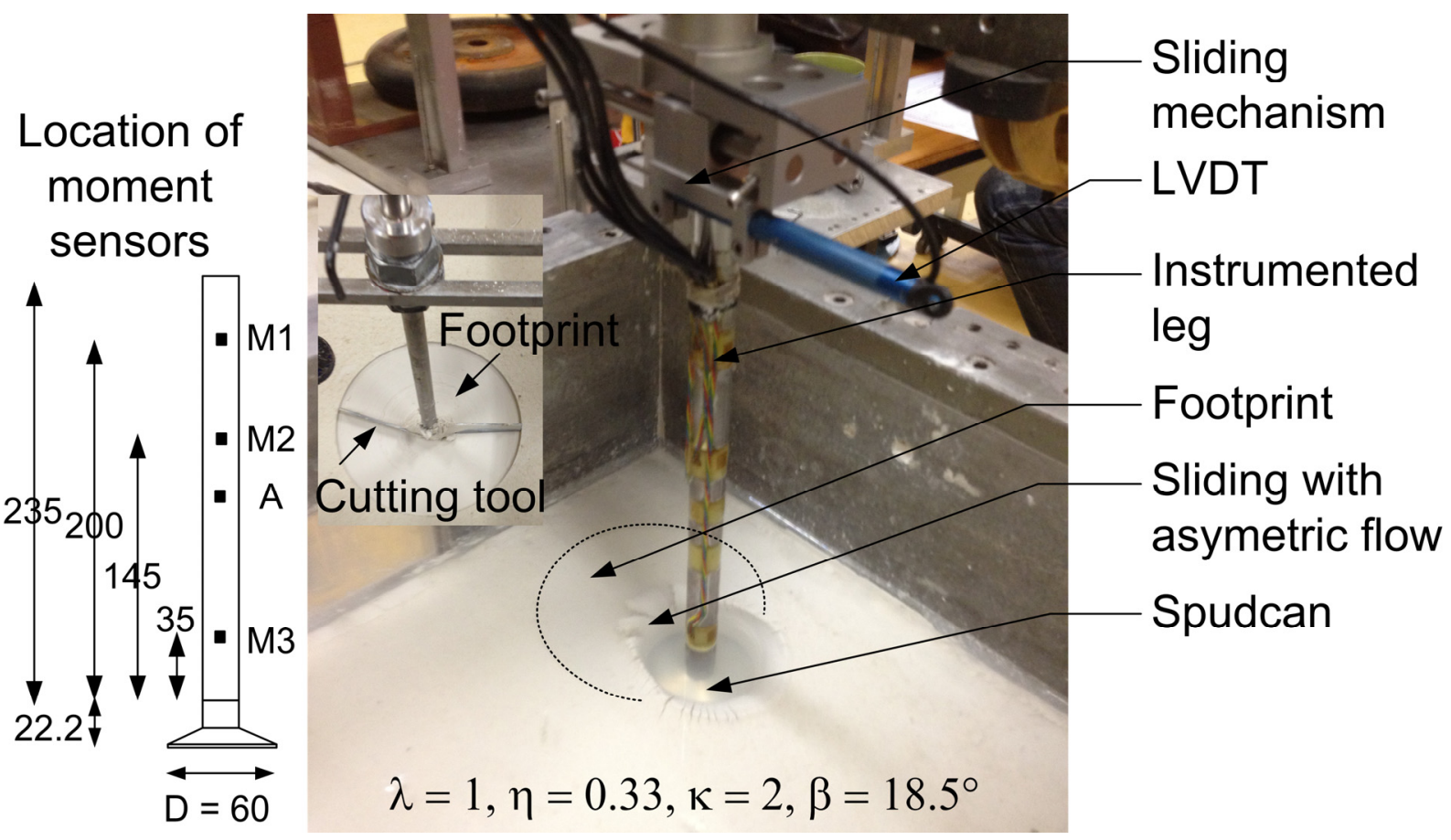

600 


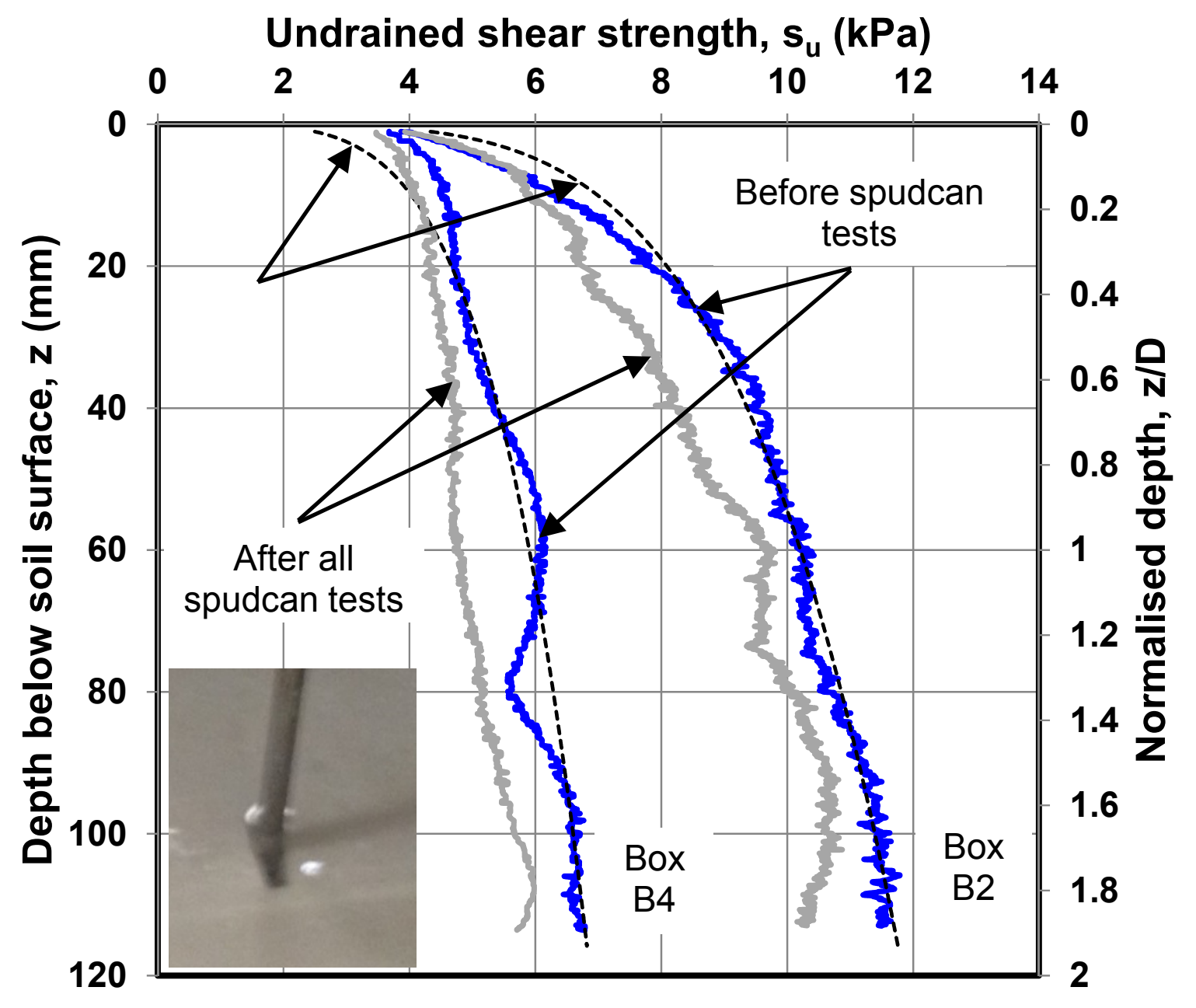

604

605 Figure 5. Undrained shear strength profiles measured before spudcan tests and after all 


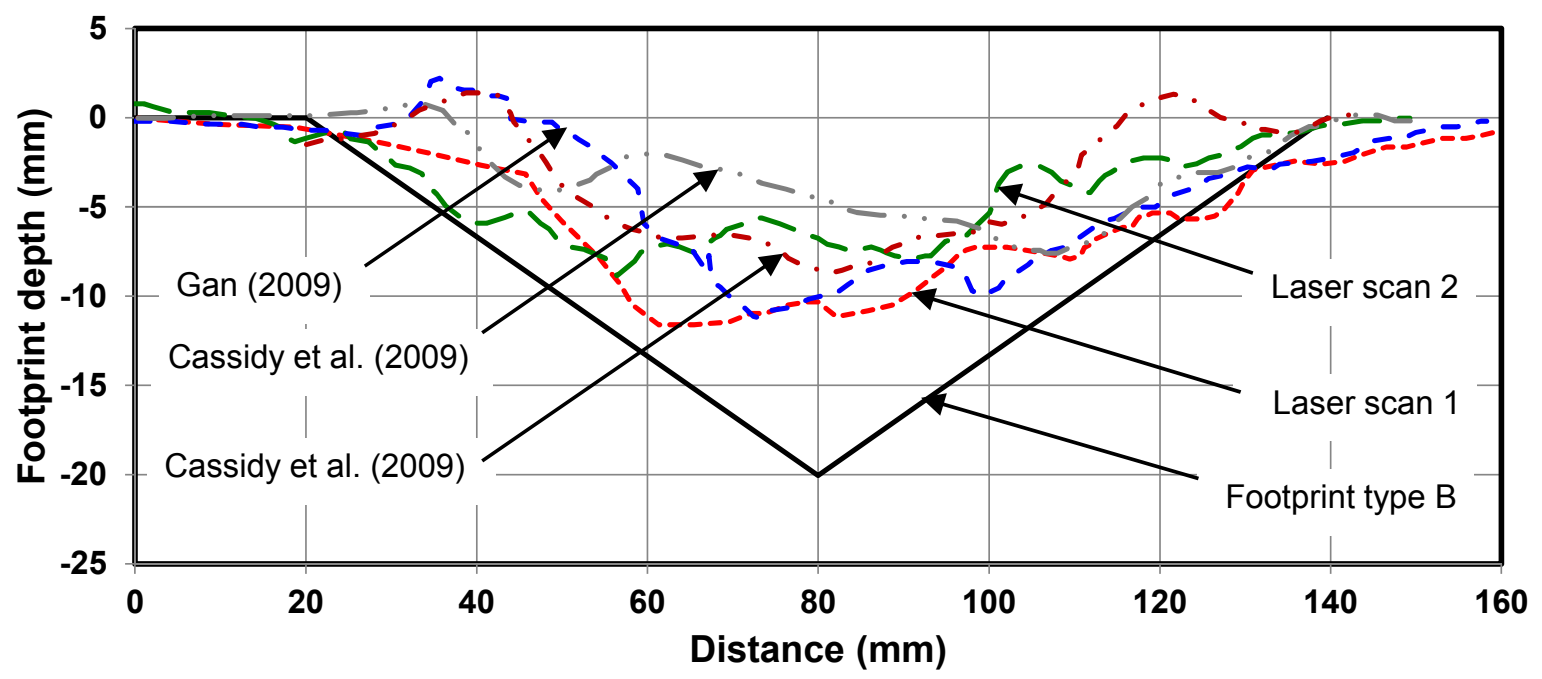

609

610 Figure 6. Comparison of footprint profiles record (data from Kong et al. 2010)

611

612

613

614

615

616 

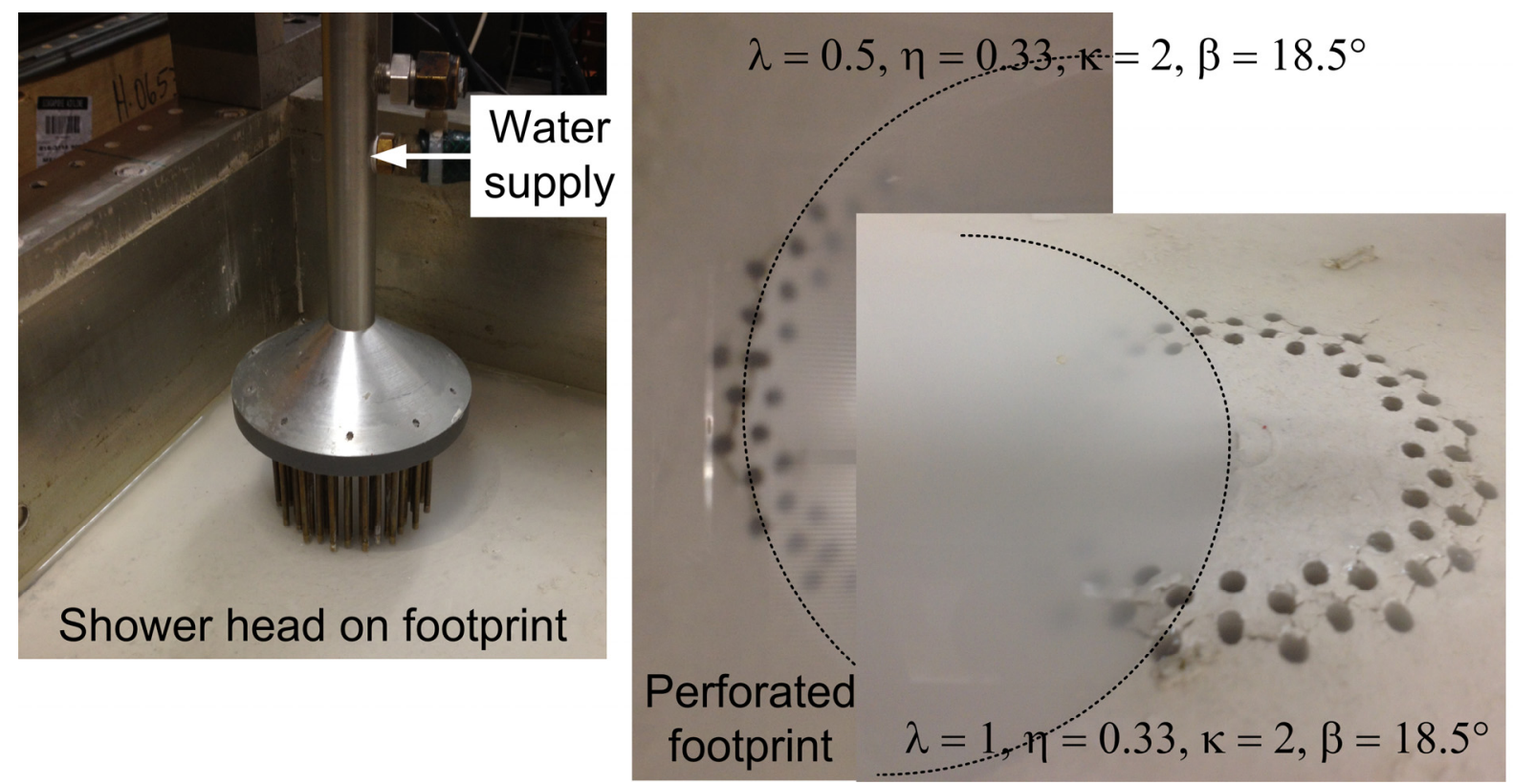

617

footprint

$\lambda=1,-1,-33, \kappa=2, \beta=18.5^{\circ}$

618 


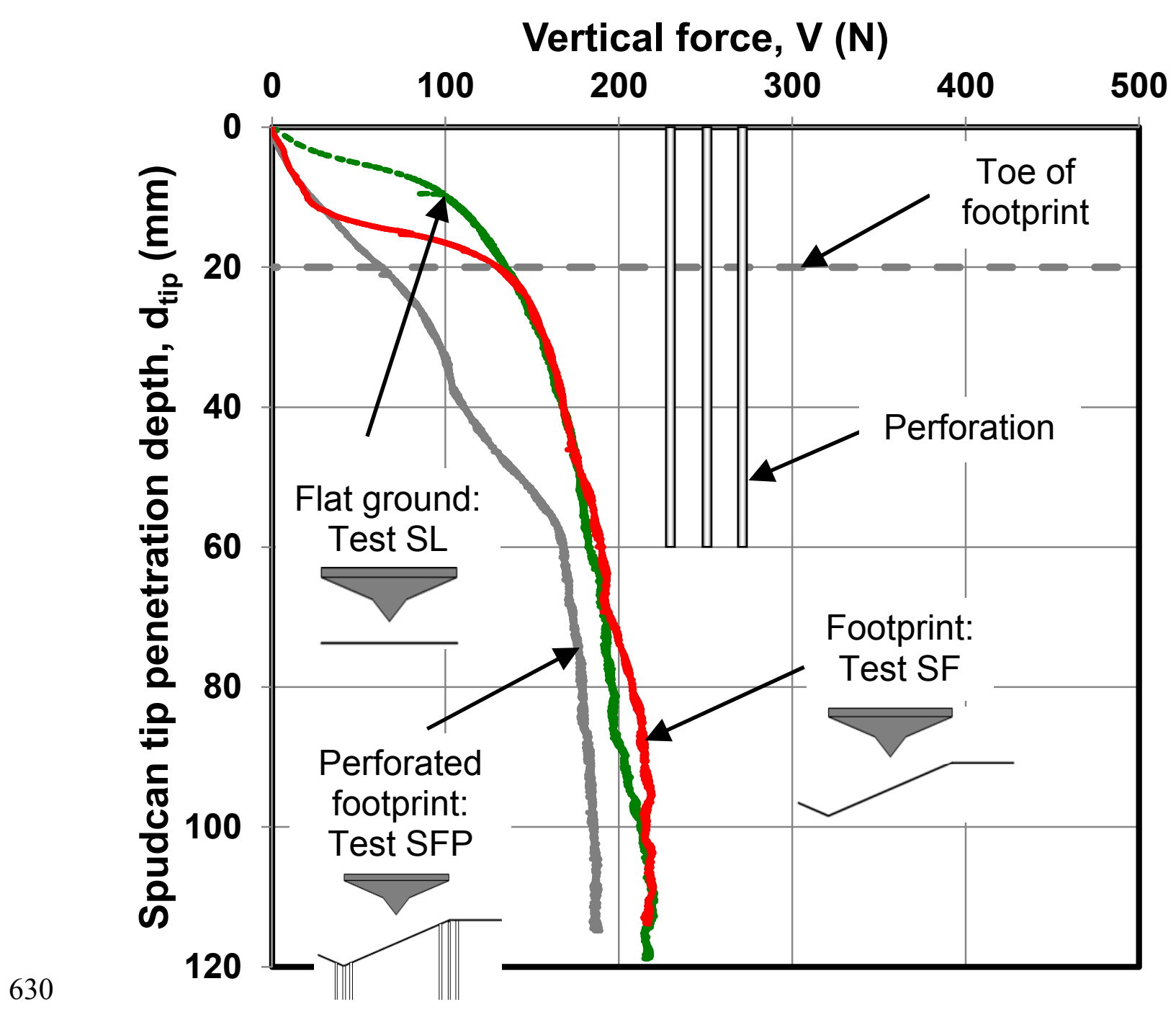

631 8(a) Load-penetration response 
Moment at base level, $\mathrm{M}_{0}$ (N.m)

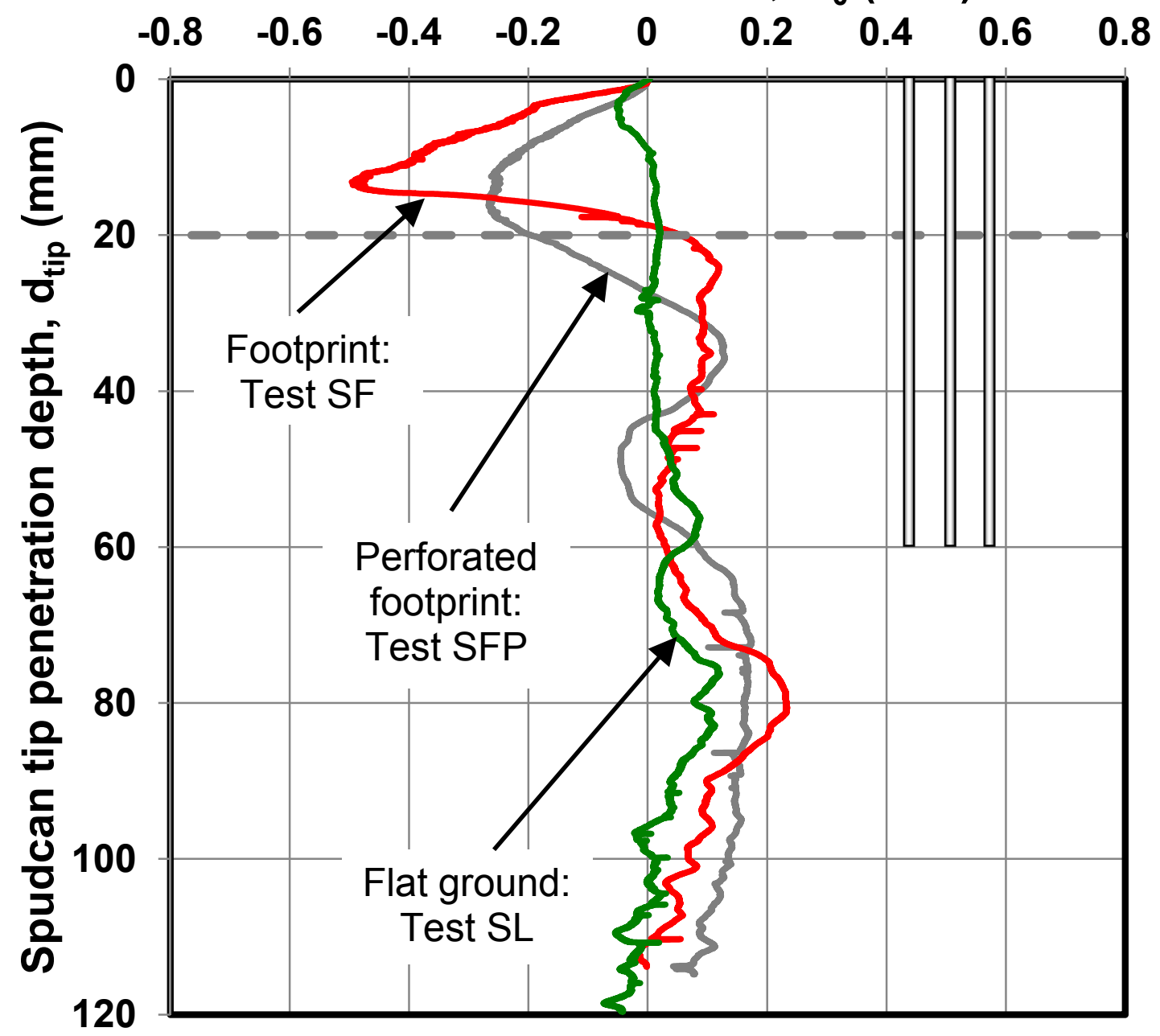

634 8(b) Moment at spudcan base level 
Horizontal displacement, $\mathrm{h}(\mathrm{mm})$

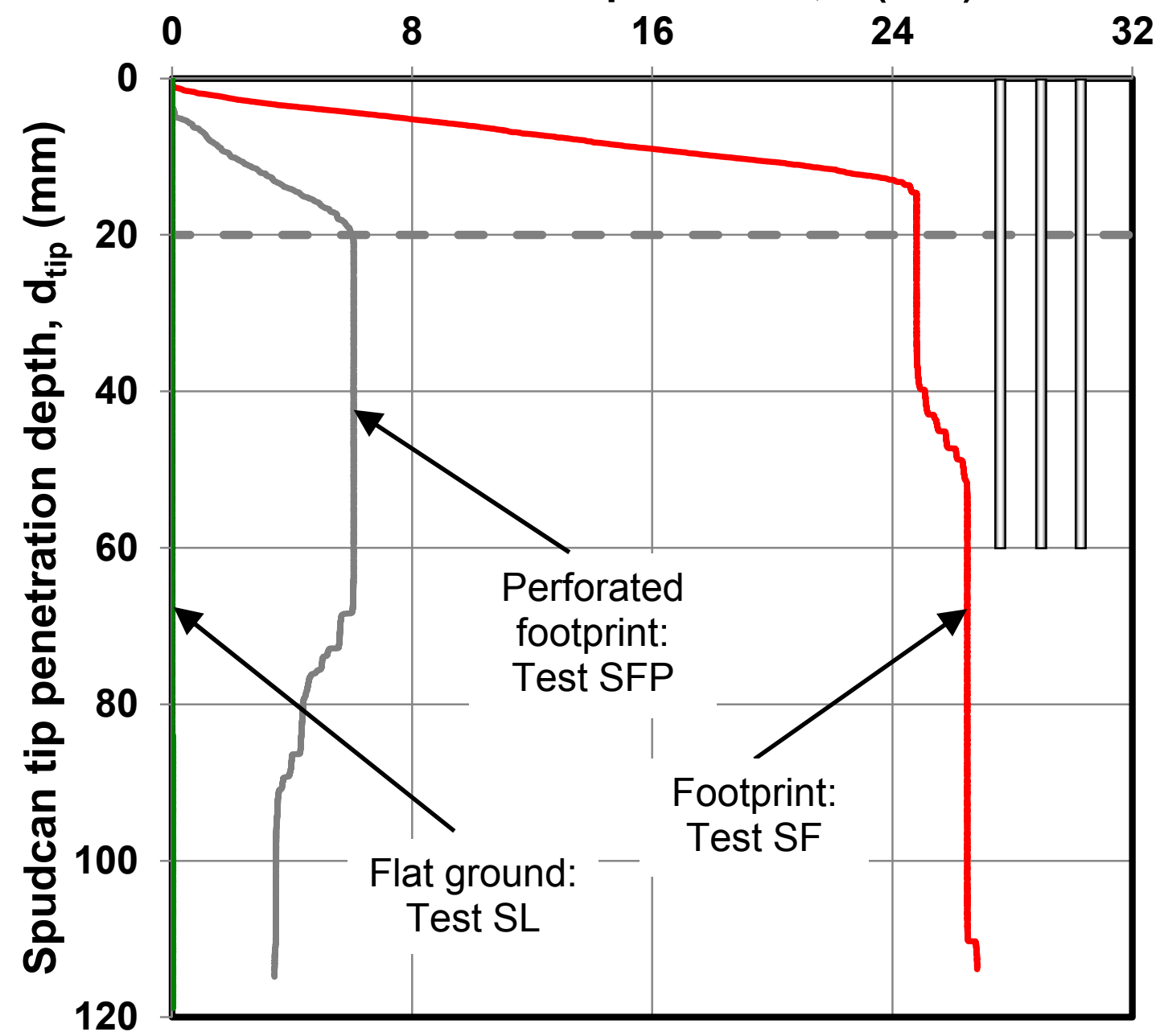

636 8(c) Sliding distance

638 Figure 8. Results of tests on Box 1: free sliding leg $\left(\lambda=0.5, \kappa=2, \eta=0.33, \beta=18.5^{\circ}\right.$; 
645 9(a) Spudcan penetration adjacent to footprint: sliding with significant soil flow to surface

646 towards footprint toe

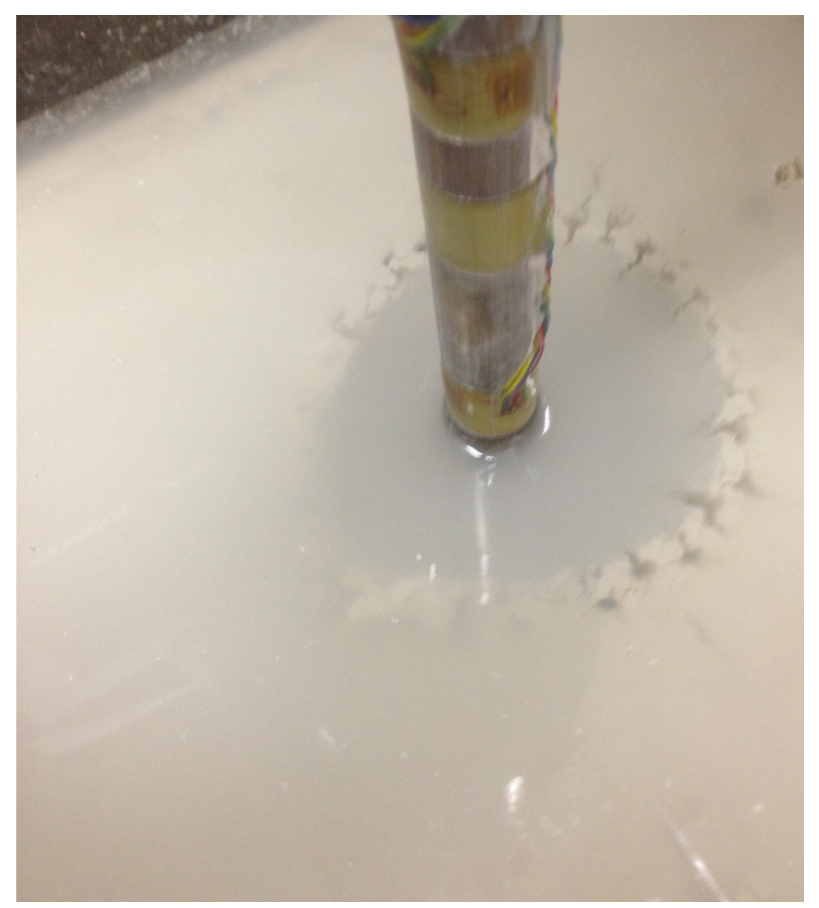

648 9(b) Spudcan penetration on perforated site adjacent to footprint: minimal sliding with little 649 soil flow to surface

651 Figure 9. Effect of perforation spudcan sliding and soil flow mechanisms $(\lambda=1, \kappa=2, \eta$

$$
=0.33, \beta=18.5^{\circ} ; \text { Box } 2 \text {, Table 1) }
$$




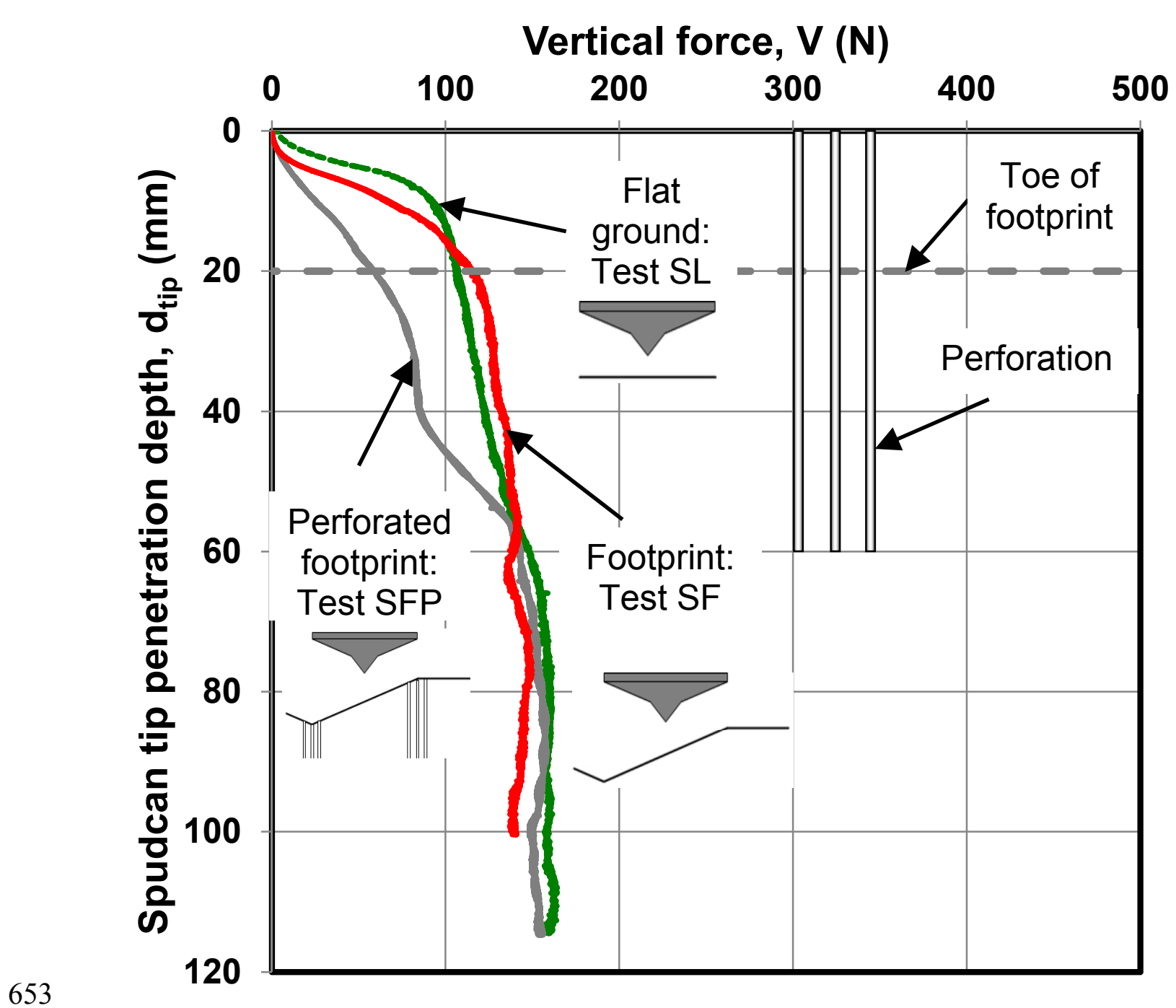

654 10(a) Load-penetration response 


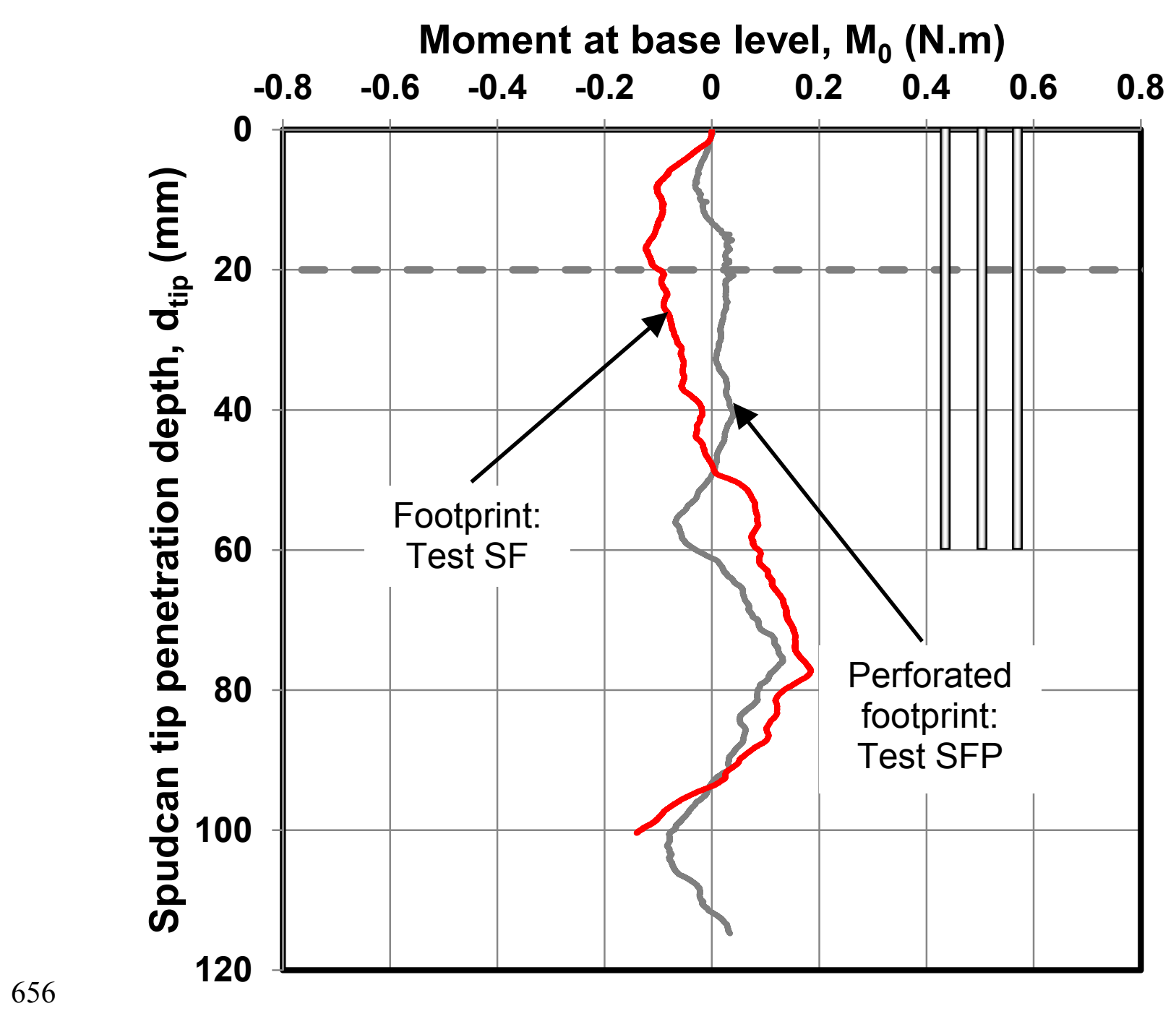

657 10(b) Moment at spudcan base level 


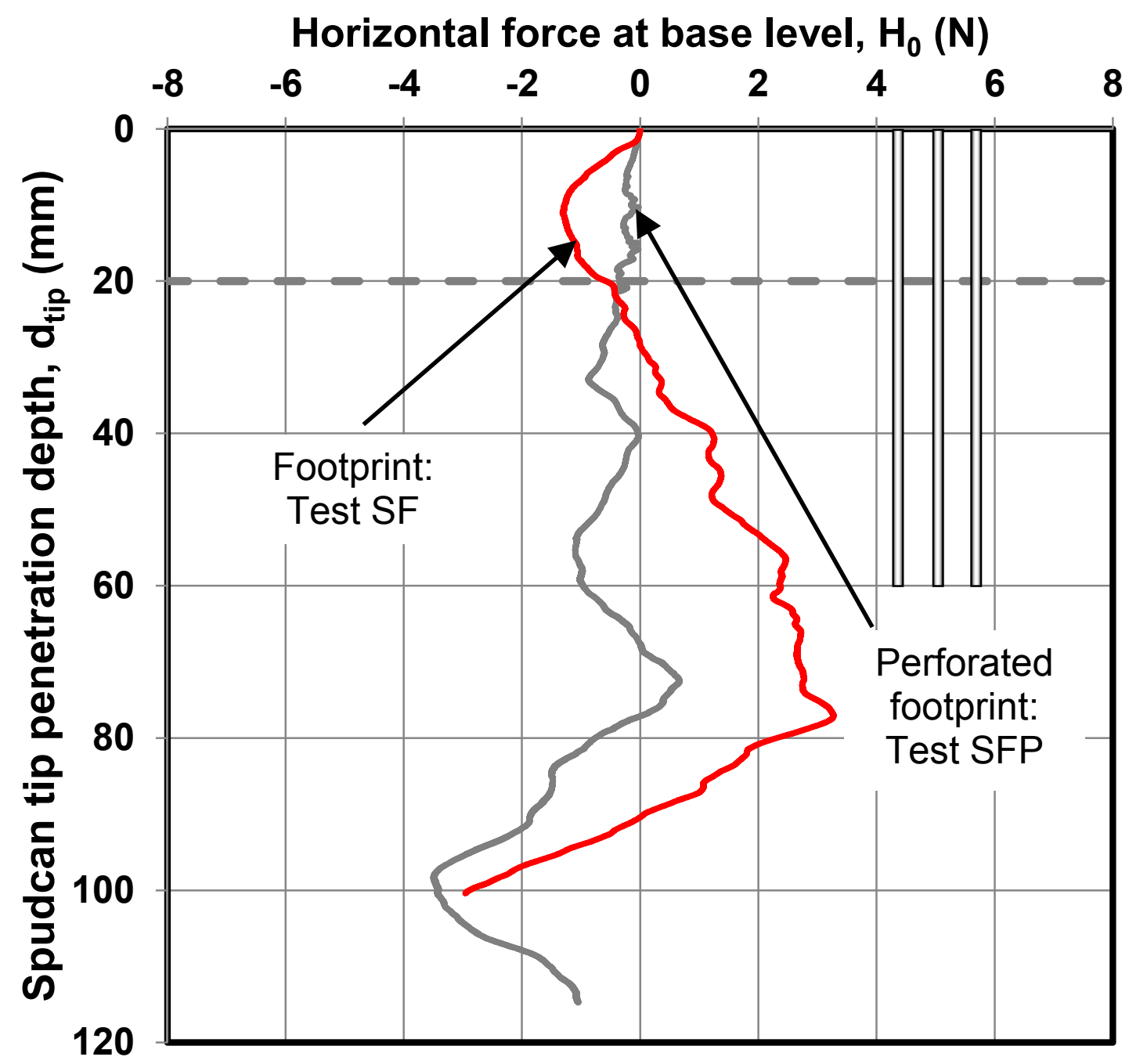

659

10(c) Horizontal force at spudcan base level

660

661 Figure 10. Results of tests on Box 4: fixed $\operatorname{leg}\left(\lambda=0.5, \kappa=2, \eta=0.33, \beta=18.5^{\circ}\right.$; Table 1)

662

663

664 


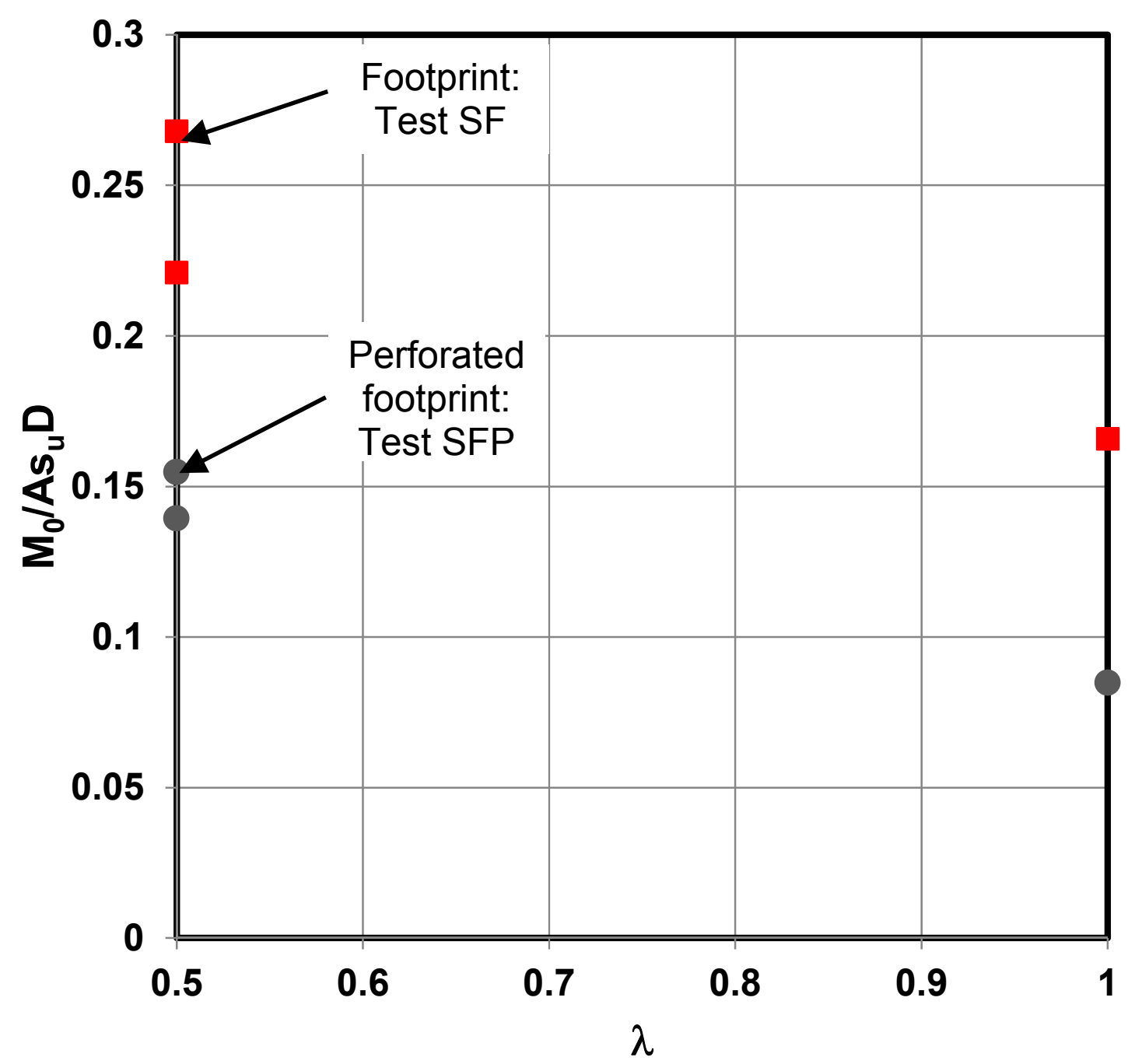

666

667 11(a) Non-dimensional moment

668 


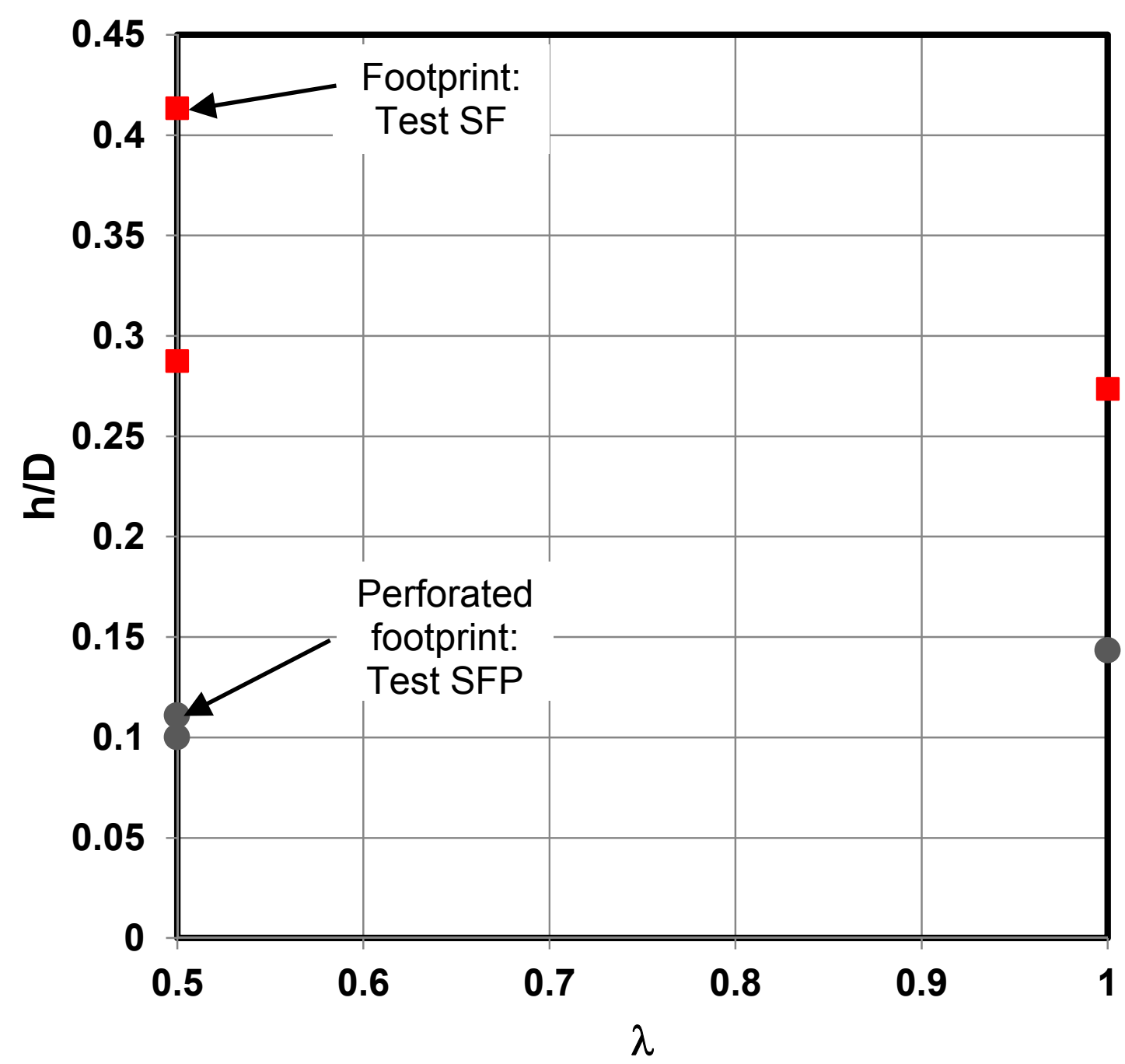

669

670 11(b) Normalised sliding

671

672 Figure 11. Effect of perforation: free sliding leg $\left(\kappa=2, \eta=0.33, \beta=18.5^{\circ} ; \operatorname{Box} 1 \sim 3\right.$,

673

Table 1)

674

675

676 


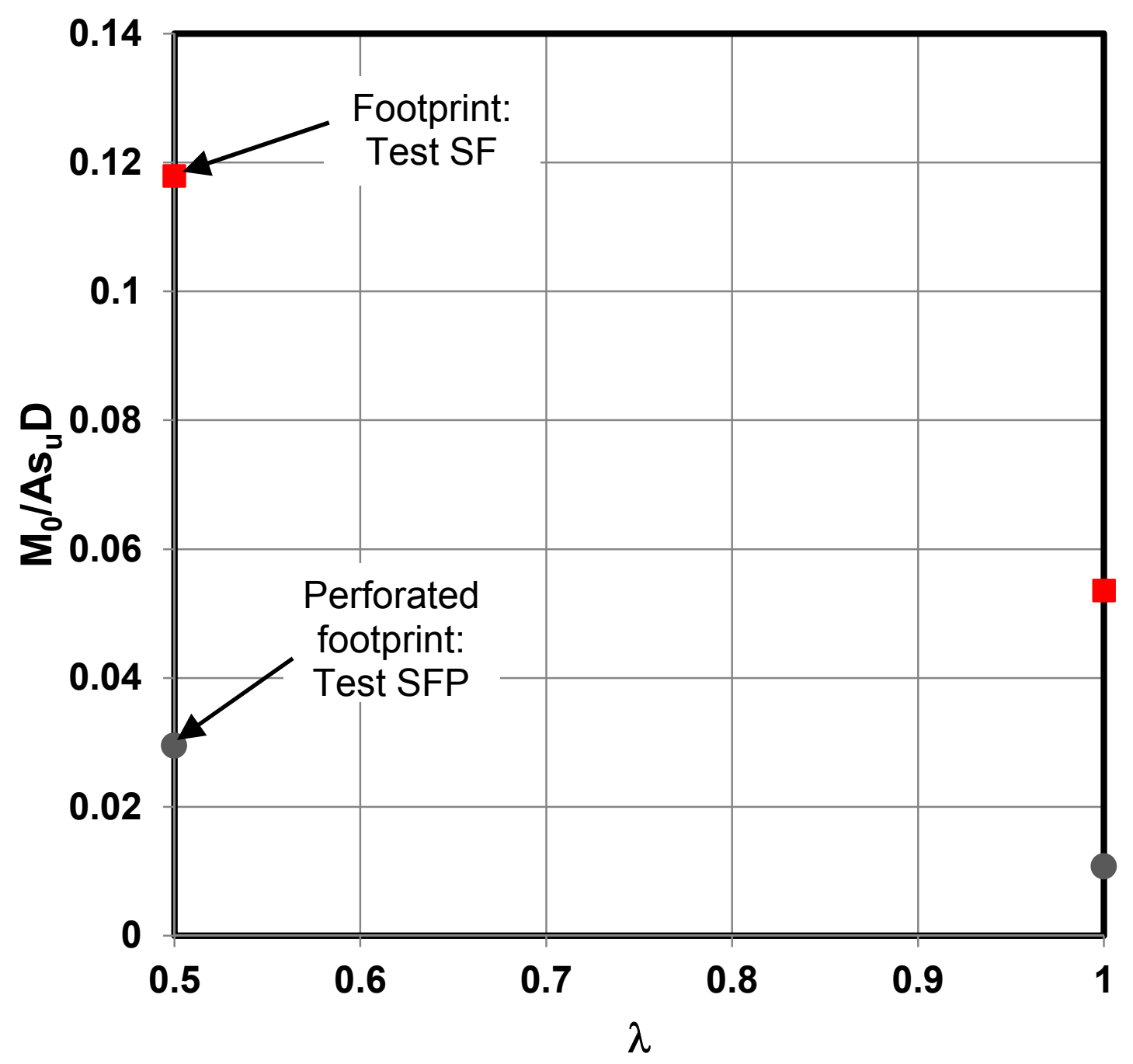

677

678 12(a) Non-dimensional moment

679 


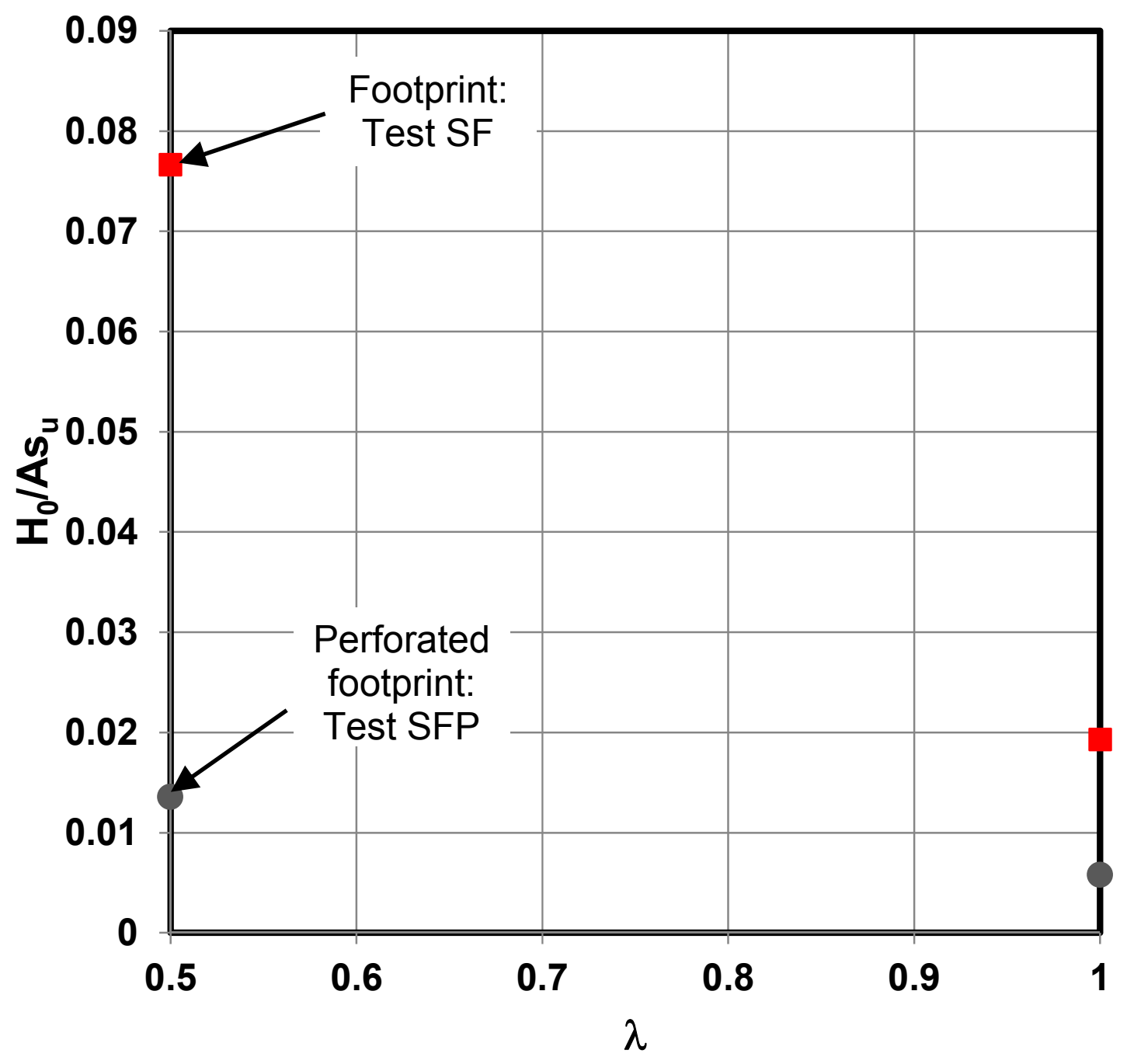

680

681 12(b) Non-dimensional horizontal force

682

Figure 12. Effect of perforation: fixed $\operatorname{leg}\left(\kappa=2, \eta=0.33, \beta=18.5^{\circ} ;\right.$ Box 4 5, Table 1) 